\title{
A CRITIQUE OF EU REFUGEE CRISIS MANAGEMENT: ON LAW, POLICY AND DECENTRALISATION
}

\author{
Nika Bačić Selanec*
}

\begin{abstract}
Summary: This article aims to uncover the legal background behind the European Union's response to the ongoing refugee crisis. Pursuant to its Agenda on Migration, the EU has implemented a wide set of legal, financial and operative measures to face the challenges of the mass inflows of refugees onto its territory. Some of these measures aim to respond to what was classified as the most pressing duty of saving lives in the Mediterranean and strengthening EU external borders. Others aim to uphold the EU's international obligations and values by assisting the third countries most affected. A core set of measures was then introduced to repair the existing EU legal framework on asylum, proven as dysfunctional when faced with the unprecedented pressures of incoming refugees. These measures came about in the context of an already deficient Common European Asylum System, yet the Union still decided to place the Dublin Regulation as a starting point for all operative plans dealing with the refugee crisis within the Union territory. Although the Dublin Regulation was not envisaged to function in a time of crisis, all the EU measures introduced were in effect merely exceptions to that inherently inefficient system. On the other hand, a true emergency mechanism was not something the Union lacked during the crucial moments of creating an operative plan for the Agenda. The existing Union framework on asylum creates two quite different concepts for determining the Member State responsible for providing international protection to refugees - one for regular asylum procedures, and another for emergency situations. By choosing the former instead of the latter, the EU went for the wrong option. The author's position is that the Union in its centralised capacity failed to activate an efficient legal framework to respond to a crisis of the present magnitude, thus creating a perfect ground for individual Member States to become the main actors of crisis management, each invoking its own political particularities and national interests. The outcome was polarisation of the Member States, every day moving farther away from the ever-closer Union.
\end{abstract}

\footnotetext{
"Nika Bačić Selanec, LLM (UMich), Research Assistant and PhD Candidate, University of Zagreb, Faculty of Law. The author would like to thank Goran Selanec for his valuable input in crystallising this article's main thesis. The usual disclaimer applies.
} 


\section{Introduction}

The ongoing refugee crisis in Europe, the biggest this world has seen in decades, has been subject to much debate - both in public, through the eyes of the media, but also in the sphere of politics. What still seems to be lacking, however, is a coherent critique of the crisis' legal setting. In other words, what has the European Union actually done in pursuing its legislative and operative agenda for managing mass inflows of refugees, as compared to what other legal avenues were available? Is the EU response adequate, and is there anything else the EU could or should have done? This paper aims to provide answers to these questions, filling in the missing pieces of the legal story.

The main claim of the author is the following. Most measures taken by the European Union in responding to the refugee crisis present nothing more than ad hoc solutions to the problems already raging on its territory or at its borders. The remaining measures are simply efforts to prevent the refugee crisis reaching the Union territory in the first place. The Union still lacks a coherent and systematic approach to crisis management in a timely manner - something that is, ironically, well within its legislative and operational capabilities. Instead, political particularities of individual Member States now seem to be prevailing, blocking an approach of solidarity that ought to be taken by an ever-closer and integrated Union. Although certain Member States' efforts did ultimately take effect, and the overall response of a decentralised Union cannot be categorised as inactive or completely inadequate, much more could and should have been done by the Union in its centralised capacity, taking great pride in its underlying values of fundamental rights protection.

The arguments to prove this claim will be presented in the following manner.

The first section will dissect the legal and political measures already taken by the European Union and will explain the efforts currently underway. The author will try to categorise these measures, aiming to uncover the background stories behind the formal actions.

The second section will then place these measures in the perspective of the Union's current legal framework of the Common European Asylum System, revealing the system's downsides and vagaries.

The third section will then explain what other legal measures within the Union legal framework were available as an alternative. It will deal with measures that the European Union could have taken in its uniform capacity, using the existing mechanisms of its legal system to more effectively and in a timelier manner respond to migratory pressures that ultimately escalated into a true refugee crisis. 
The final section will try to explain the consequences of the Union policy in managing the unstoppable mass inflows of refugees, political and otherwise. It will also assess its impact for the future of an evercloser Union, or at least the idea that should have existed thereof.

Some concluding remarks will follow.

\section{Managing the refugee crisis: Operationalising the European Agen- da on Migration}

Escalation of migratory pressures in the early 2010s came as no surprise to the general public considering the geopolitical background of the Middle East and North Africa, and especially the raging Syrian civil war. Yet no European actor took the matter seriously enough until the migratory pressures resulted in grave tragedies and numberless lives lost at sea of those fleeing war and persecution in their respective countries of origin. Starting with the 2013 Lampedusa shipwreck that cost the lives of more than 500 migrants en route for Italy, the Mediterranean soon started counting the loss of lives in thousands. ${ }^{1}$ The main turning point for the European Union came after the media outburst following the 19 April 2015 tragedy, when a migrant boat sank just off Libya resulting in more than 800 dead men, women and children. Apparently, early 2015 witnessed a $1,600 \%$ increase in the number of migrants drowning while attempting to cross the Mediterranean as compared to the same period in early $2014 .^{2}$

A European Council meeting on 23 April 2015 was the first to call upon the Commission to respond to the need to undertake coordinated Union action to prevent further loss of life at sea by strengthening the presence of naval forces in the Mediterranean and fighting human smugglers and traffickers. ${ }^{3}$ The European Council also reiterated the importance of 'preventing illegal migration flows and reinforcing internal solidarity and responsibility' of the Member States. Just a few days later, the European Parliament continued in that vein, adopting a resolution to urge both the EU and the Member States to "build on the existing coop-

\footnotetext{
1 UNHCR reports that 3,500 lives were lost in 2014, and 1,600 in the first quarter of 2015. For more information on Mediterranean tragedies, see UNHCR, 'New Mediterranean Boat Tragedy May Be Biggest Ever, Urgent Action is Needed Now' (19 April 2015) <http://www. unhcr.org/5533c2406.html> accessed 30 December 2015.

2 See 'What's Behind the Surge in Refugees Crossing the Mediterranean Sea' The New York Times (New York, 20 April 2015) <http:/ / www.nytimes.com/interactive/2015/04/20/ world/europe/surge-in-refugees-crossing-the-mediterranean-sea-maps.html?_r=0> accessed 30 December 2015.

3 Special meeting of the European Council, 23 April 2015 - Statement, paras 1-3 <http:// www.consilium.europa.eu/en/press / pressreleases /2015/04/23-special-euco-statement/> accessed 30 December 2015.
} 
eration in the Common European Asylum System and do everything possible to prevent further loss of life at sea'. ${ }^{4}$ All relevant actors were called upon 'to take a comprehensive European approach and step up fair sharing of responsibility and solidarity between Member States'. ${ }^{5}$

The Commission's response to the migratory pressures soon followed the European Council and the Parliament, bringing about the 13 May 2015 European Agenda on Migration ${ }^{6}$ as a cornerstone of the Union's actions for tackling the refugee crisis.

The Agenda set out a core system of EU measures in pursuing a consistent and clear common policy on migration. A new, more European approach was set as a priority. In other words, coordinated action at the European level, based on principles of solidarity and shared responsibility, was presented as the only effective way for Europe to meet its international and ethical obligations ${ }^{7}$ towards those fleeing persecution and war. ${ }^{8}$

The system of measures envisaged in the Agenda may be categorised in three main groups based on their material and territorial scope. The first group of measures aims to resolve what was classified as the most pressing duty of saving lives at sea, ${ }^{9}$ together with protecting the Union borders. The second one encompasses Union efforts in the international arena to uphold its international obligations and values. The ultimate goal of the second set of measures is yet again to secure the Union external borders, alongside the humanitarian approach. ${ }^{10}$ The final group of introduced emergency measures aims to repair internally the existing European policy on asylum that has proven to fall short faced with the pressure of thousands of migrants. ${ }^{11}$ These measures specifically include

\footnotetext{
4 European Parliament, Resolution on the latest tragedies in the Mediterranean and EU migration and asylum policies, 2015/2660(RSP) para 1. < http:/ /www.europarl.europa.eu/ oeil/popups / ficheprocedure.do?lang=en\&reference $=2015 / 2660$ (RSP) $>$ accessed 30 December 2015.

5 ibid, para 3; see also Article 80 TFEU.

6 Commission 'A European Agenda on Migration' (Communication) COM (2015) 240 final (hereinafter: the European Agenda on Migration, the Agenda on Migration, or Agenda).

7 Referring to the 1951 Geneva Convention Relating to the Status of Refugees that is signed and ratified by all EU Member States: UN General Assembly, 'Convention Relating to the Status of Refugees' (28 July 1951) UN, Treaty Series vol 189, 137; as amended by the 'Protocol relating to the Status of Refugees' (31 January 1967) UNTS vol 606, 267 (hereinafter: Geneva Convention).

8 Agenda on Migration (n 6) 2.

9 ibid: 'The immediate imperative is the duty to protect those in need. The plight of thousands of migrants putting their lives in peril to cross the Mediterranean has shocked us all.'

10 ibid: 'we need to use the EU's global role and wide range of tools to address the root causes of migration.... Upholding our international commitments and values while securing our borders...'

11 ibid: 'Emergency measures have been necessary because the collective European policy on the matter has fallen short. ... across Europe, there are serious doubts about whether our migration policy is equal to the pressure of thousands of migrants...'
} 
quotas for internal relocation, the revision of the Dublin Regulation, ${ }^{12}$ and the more stringent application of CEAS rules.

So far, two sets of implementation packages have been introduced by the European legislator or the Commission to operationalise the measures envisaged in the Agenda on Migration. ${ }^{13}$ Instead of focusing on many technicalities in the implementation packages, this author will categorise the undertaken measures pursuant to the objectives these measures aim to pursue, taking into account their material and territorial scope.

\subsection{Saving lives in the Mediterranean and strengthening EU borders}

Set out as the immediate priority for Union action, saving lives in the Mediterranean while also strengthening the Union's maritime borders was the immediate priority for action and was actually the most effective set of measures undertaken by the Union.

The EU has been funding its agency Frontex ${ }^{14}$ to patrol the Mediterranean waters since 2006, starting with the Frontex-led Operation Poseidon in the eastern Mediterranean just off the Greek shores. Shortly after the aforementioned Lampedusa shipwreck, another naval operation called Mare Nostrum was launched in 2013 by the Italian navy to patrol waters close to Italian shores. In October 2014, coordination of the operation was taken over by Frontex, now EU-funded and renamed Operation Triton. This operation, like the Greek counterpart Operation Poseidon, aimed not only at preventing further loss of life at sea, but also at reinforcing EU maritime border surveillance. ${ }^{15}$ Following the measures called upon by the European Council and later set out in the Agenda on Migration, the Commission tripled the capacities and budgetary assets

\footnotetext{
12 European Union, Regulation (EU) No 604/2013 of the European Parliament and of the Council of 26 June 2013 establishing the criteria and mechanisms for determining the Member State responsible for examining an application for international protection lodged in one of the Member States by a third-country national or a stateless person [2013] OJ L180 (hereinafter: the Dublin Regulation) 31-59.

13 For detailed information on the exact measures implemented by the European legislator or the Commission, see Commission, Migration and Home Affairs, 'European Agenda on Migration - Legislative documents' <http:/ / ec.europa.eu/dgs/home-affairs/what-we-do/policies/european-agenda-migration/proposal-implementation-package/index_en.htm> accessed 30 December 2015 or Commission, Migration and Home Affairs, 'European Agenda on Migration - Factsheets' <http://ec.europa.eu/dgs/home-affairs/what-we-do/policies / european-agenda-migration/background-information/index_en.htm> accessed 30 December 2015.

14 The European Agency for the Management of Operational Cooperation at the External Borders of the Member States of the European Union was established by Council Regulation (EC) 2007/2004 [2004] OJ L349.

15 See European Council \& Council of the EU, Migratory Pressures, 'Saving Lives at Sea and Targeting Criminal Networks' <http:/ /www.consilium.europa.eu/en/policies/migratory-pressures/saving-lives-targeting-criminal-networks/> accessed 30 December 2015.
} 
of these Frontex-led, now joint-operations ${ }^{16}$ Triton and Poseidon in 2015 and $2016 .{ }^{17}$

In addition to saving lives in the Mediterranean, the EU actions, based on the Agenda, included targeting criminal networks of smugglers and traffickers of migrants and refugees in the Mediterranean. For that purpose, the Council Decision of 18 May $2015^{18}$ formally established for the first time an EU military operation, named EUNAVFOR Med. ${ }^{19}$ The operation was launched in June 2015, first focusing on the surveillance and assessment of human smuggling and trafficking networks. As of October 2015, the operation was given an expanded mandate to include actions of boarding, search, seizure and diversion on the high seas of suspicious vessels, all under the conditions prescribed under international law. ${ }^{20}$ This expanded mandate was followed by renaming the operation Operation Sophia. ${ }^{21}$

Results of the EU-coordinated naval operations for saving lives in the Mediterranean very soon emerged. The number of people who drowned or disappeared at sea in their attempts to reach European shores declined dramatically in the months following the deployment of naval forces. The

16 Frontex reports that 26 European countries are taking part in joint operations by deploying experts and technical equipment: Austria, Belgium, Croatia, Czech Republic, Denmark, Estonia, Finland, France, Germany, Greece, Iceland, Ireland, Latvia, Lithuania, Luxembourg, Malta, Netherlands, Norway, Poland, Portugal, Romania, Slovenia, Spain, Sweden, Switzerland and UK. For more information, see Frontex, 'Frontex Expands Its Joint Operation Triton' (26 May 2015) <http://frontex.europa.eu/news/frontex-expands-its-jointoperation-triton-udpbHP> accessed 30 December 2015 .

17 European Parliament Resolution of 7 July 2015 on the Council position on Draft amending budget No 5/2015 of the European Union for the financial year 2015 - Responding to migratory pressures (09768/2015 - C8-0163/2015 - 2015/2121(BUD)). Frontex reports that the Commission will provide an additional EUR 26.25 million to strengthen Operation Triton in Italy and Poseidon in Greece from June 2015 until the end of the year. The budget for Triton for 2015 will amount to EUR 38 million and EUR 18 million for Poseidon. See Frontex, 'Frontex Expands its Joint Operation Triton' (26 May 2015) <http://frontex.europa.eu/news/frontex-expands-its-joint-operation-triton-udpbHP> accessed 30 December 2015.

18 Council Decision (CFSP) 2015/778 of 18 May 2015 on a European Union military operation in the Southern Central Mediterranean (EUNAVFOR MED) [2015] OJ L122/31

19 The operation does not deploy or create the EU's own military assets, but is based on the operative contributions of 14 EU Member States (BE, DE, EL, ES, FI, FR, HU, IT, LT, LU, NL, SE, SI, UK). For more information on this Council-coordinated military operation and the rules on its phases and functioning, see European Union Naval Force - Mediterranean, 'Operation Sophia'<http://www.eeas.europa.eu/csdp/missions-and-operations/eunavformed/pdf/factsheet_eunavfor_med_en.pdf> accessed 30 December 2015.

20 See European Council \& Council of the EU, 'EUNAVFOR Med: EU agrees to start the active phase of the operation against human smugglers and to rename it "Operation Sophia"' (28 September 2015) <http://www.consilium.europa.eu/en/press/pressreleases/2015/09/28-eunavfor/> accessed 30 December 2015.

21 The operation was renamed Sophia after the name given to a baby that was born on a ship participating in the EUNAVFOR Med operation. 
death rate between January and April 2015 was 1 in 16, or $6.2 \%$, while the numbers between April and June of the same year were significantly reduced to 1 in 427 , or $0.23 \%$. Amnesty International marked these numbers as a massive improvement in the situation. ${ }^{22}$

On the other hand, strengthening the EU's external land borders, deemed as fundamental for managing the migration flows within the $\mathrm{EU},{ }^{23}$ fell short of the success witnessed in the maritime actions.

The basic idea behind the Agenda on Migration was to achieve effective control of the EU's external borders by strengthening the marginal role and capacities of Frontex as an EU-based agency, both in operative and financial terms. ${ }^{24}$ Frontex was determined to work on the ground with frontline Member States to swiftly identify, register, fingerprint (or return some of the incoming refugees and migrants by utilising new technologies ${ }^{25}$ to create a more effective border control system. The so-called hotspot approach was envisaged by the Commission as a coordinated operation of the European Asylum Support Office, Frontex and Europol to provide help to the frontline Member States. The intention was to activate the system in all Member States dealing with mass influxes at the EU's external borders, such as Italy, Greece, but also Hungary and Croatia as the first Member States on the Western Balkans route. ${ }^{26}$ Due to the politically sensitive connotation of being referred to as a hotspot area, both of the latter countries refused. The newly established Migration Management Support Teams (MMST) that put the hotspot system into operation were deployed only to Greece and Italy. ${ }^{27}$

Mass inflows of refugees and migrants coming towards the Union through the Western Balkans route, however, required assistance to be

\footnotetext{
22 Amnesty International, 'A Safer Sea: The Impact of Increased Search and Rescue Operations in the Central Mediterranean, Public Statement (9 July 2015) <https://www.amnesty.org/download/Documents/EUR0320592015ENGLISH.pdf> accessed 30 December 2015.

23 European Council \& Council of the EU, Migratory Pressures, 'Strengthening the EU's External Borders' <http://www.consilium.europa.eu/en/policies/migratory-pressures/ strengthening-external-borders/> accessed 30 November 2015.

24 Agenda on Migration (n 6) 6, 10.

25 See, for example, Commission Staff Working Document on Implementation of the Eurodac Regulation as regards the obligation to take fingerprints, SWD(2015) 150 final; or Regulation 1052/2013 of 22 October 2013 establishing the European Border Surveillance System (EUROSUR): an information-exchange system designed to improve management of the EU external borders [2013] OJ L295; see also the Agenda on Migration (n 6) 11, on the initiative of introducing 'Smart Borders'.

26 For more information on the Western Balkans route, see 'Migratory Routes Map' < http:// frontex.europa.eu/trends-and-routes/migratory-routes-map/> accessed 30 December 2015.

27 See Commission, 'Managing the refugees crisis: immediate operational, budgetary and legal measures under the European Agenda on Migration' (Communication) COM (2015) 490 final/2 - Annex II: Migration Management Support Teams working in 'hotspot' areas.
} 
provided to the most affected Member States who refused to be considered a hotspot. The Commission thus responded by strengthening the capacities of the Frontex-coordinated Rapid Border Intervention Teams (RABIT), ${ }^{28}$ and emphasising to the Member States that they can request the deployment of such teams at any time, and receive immediate border guard support. ${ }^{29}$ Through MMST, RABIT, bilateral agreements or some other form of cooperation, Frontex has so far dispatched border support to Greece, Italy, Hungary, Bulgaria, Croatia and Slovenia. ${ }^{30} \mathrm{Howev-}$ er, all these Frontex-coordinated actions have proven incapable of much success or results in the context of the unstoppable inflows of refugees coming through the Western Balkans route, ${ }^{31}$ as well as in relation to the complex problems faced by the Member States in their effective and timely registration and processing. ${ }^{32}$

\subsection{The international arena}

The Agenda on Migration sets out to tackle the global issues of the refugee crisis as another of the Union's main priorities, emphasising the importance of a broad approach and strong cooperation with the countries of origin and transit. ${ }^{33}$ Key actions to be undertaken by the Union in the international arena are to address the root causes of irregular migration through development, cooperation with third countries and providing international humanitarian or financial assistance. ${ }^{34}$ In addition to the Union truly stepping up to its humanitarian obligations, this effectively means that the Union is trying to find logistical solutions for the refugee crisis to stay outside the EU external borders.

\footnotetext{
28 ibid, ANNEX III: The Rapid Border Intervention Teams mechanism (RABIT). The RABIT mechanism was established by Regulation (EC) No 863/2007 [2007] OJ L199 whereby Frontex funds and deploys technical and human resources from EU Member States.

29 ibid, 6.

30 See Leaders' Meeting on Refugee Flows Along the Western Balkans Route, 'Leaders' Statement' available at <http://ec.europa.eu/news/2015/docs/leader_statement_final. pdf $>$ accessed 30 December 2015

${ }_{31}$ For Frontex facts and figures on the Western Balkans route, see <http://ec.europa.eu/ news/2015/docs/eastern_border_wb_2015_presentation.pdf> accessed 30 November 2015. 32 A special meeting on the challenges of dealing with the unprecedented flow of refugees and migrants along the Eastern Mediterranean-Western Balkans route was also subject to a special meeting of leaders of the affected EU and non-EU countries in Brussels on 25 October 2015, initiated by the European Commission. For more details, see <http://europa.eu/rapid/press-release_IP-15-5924_en.htm> or <http://ec.europa.eu/ news/2015/10/20151025_en.htm>. The 'Leaders' Statement' is available at <http:// ec.europa.eu/news/2015/docs/leader_statement_final.pdf>. All sites accessed 30 November 2015.

${ }^{33}$ See Agenda on Migration (n 6) 7; see also European Council \& Council of the EU, Migratory Pressures, 'Preventing Illegal Migration Flows'<http://www.consilium.europa.eu/en/ policies/migratory-pressures/preventing-illegal-migration-flows/> accessed 30 December 2015.

34 Agenda on Migration (n 6) 10.
} 
In June 2015, the European Council called upon the Union to 'step up cooperation with Turkey and other relevant countries in the Middle East, including Iraq, Jordan and Lebanon'. ${ }^{35}$ Following that commitment, in September 2015 the Council agreed to 'assist Lebanon, Jordan, Turkey and other countries in dealing with the Syrian refugee crisis and mobilise at least $€ 1$ billion in additional funding for the UN High Commissioner for Refugees and the World Food Programme'. ${ }^{36}$

Partnership with countries of origin and transit by means of bilateral and regional cooperation frameworks on migration would take place by 'stepping up the role on migration of EU Delegations in key third countries', ${ }^{37}$ by technical and operative support given to those third countries by means of deploying 'European migration liaison officers'38 in EU Delegations and, finally, by providing those third countries with 'substantial financial assistance'. ${ }^{39}$

The most intensive cooperation and political dialogue has been made with Turkey as the country hosting the greatest number of refugees worldwide. ${ }^{40}$ In addition to strengthening cooperation to more effectively prevent irregular migration, the joint EU-Turkey action aimed to support Syrian refugees and their hosting communities in Turkey, discouraging them from reaching the Union borders and reducing their incentive to move towards the EU. In exchange, the Union would provide Turkey with substantial operative and financial assistance. ${ }^{41}$

In a broader context, ${ }^{42}$ supporting the efforts of hosting refugees

\footnotetext{
35 European Council, European Council Meeting (25 and 26 June 2015) - Conclusions, Brussels, 26 June 2015 (OR en) EUCO 22/15, 5.

36 See European Council \& Council of the EU, Migratory Pressures, 'Preventing Illegal Migration Flows' <http://www.consilium.europa.eu/en/policies/migratory-pressures/preventing-illegal-migration-flows/> accessed 30 December 2015.

37 Agenda on Migration (n 6) 8.

38 Council Regulation (EC) No 377/2004 of 19 February 2004 [2004] OJ L64/1: 'The Immigration Liaison Officers are representatives of the Member States who are posted in a non-Member State in order to facilitate the measures taken by the EU to combat irregular immigration'.

39 See Agenda on Migration (n 6) 8: "The EU is a leading international donor for refugees with EUR 200 million in ongoing projects from development assistance and over EUR 1 billion of humanitarian assistance dedicated to refugees and IDPs since the beginning of 2014'.

40 European Commission, Joint Communication to the European Parliament and the Council 'Addressing the Refugee Crisis in Europe - The Role of EU External Action, JOIN (2015)40 final, 5.

41 For more information, see 'EU-Turkey Joint Action Plan' < http:/ / ec.europa.eu/priorities / migration/docs/20151016-eu-revised-draft-action-plan_en.pdf> accessed 5 December 2015. 42 For other types of global humanitarian assistance initiated by the EU see, for example Commission, International Cooperation and Development, 'Emergency Trust Fund for Stability and Addressing Root Causes of Irregular Migration and Displaced Persons in Africa' <http://ec.europa.eu/europeaid/emergency-trust-fund-stability-and-addressing-
} 
from Syria and Iraq, the EU mobilised EUR 855 million in 2015 for humanitarian assistance within those countries, but also within refugee camps in Lebanon, Jordan and Turkey. ${ }^{43}$ The European Union has also stepped up its support for the non-EU Western Balkans countries, such as Serbia and Macedonia, which are currently receiving unprecedented flows of refugees on their way to the EU. ${ }^{44}$

In addition to providing assistance to third countries hosting refugees, the EU has agreed to resettle a certain number of persons in clear need of international protection from third countries to the EU Member States through multilateral and national schemes. The Agenda on Migration aimed to introduce this resettlement mechanism to improve the management of legal migration and asylum flows. On 25 June 2015, the European Council agreed ${ }^{45}$ that all Member States would participate in resettling 20,000 people in need of international protection from the most affected and endangered areas, pursuant to a specific distribution key. ${ }^{46}$ Details of the proposed resettlement were set down in the Council conclusions of 20 July $2015 .{ }^{47}$ Introducing this measure, and taking over 20,000 people in need of international protection from third countries to the European Union on purely humanitarian grounds may surely be welcomed. However, this measure must be viewed in a broader context to reveal its true impact. Before the Commission proposal on the EU-based act on resettlement, Member States had since 2013 already pledged in their individual capacities to resettle 38,000 refugees from third countries into their own territories. Interestingly enough, $78 \%$ of those places

root-causes-irregular-migration-and-displaced-persons_en> accessed 30 November 2015; Commission, 'Member State and Commission Contributions to World Food Programme' $<$ http: / / ec.europa.eu/dgs/home-affairs / what-we-do/policies / european-agenda-migration/proposal-implementation-package/docs/communication_on_managing_the_refugee_ crisis_annex_5_en.pdf> accessed 30 November 2015; and Commission, 'The EU Regional Trust Fund ("MADAD Trust Fund") in Response to the Syrian Crisis' < http://ec.europa.eu/ dgs/home-affairs / what-we-do/policies/european-agenda-migration/proposal-implementation-package/docs/communication_on_managing_the_refugee_crisis_annex_6_en.pdf> accessed 30 November 2015.

43 European Commission, Joint Communication to the European Parliament and the Council, 'Addressing the Refugee Crisis in Europe: The Role of EU External Action' JOIN (2015) 40 final, 5

44 ibid, 6: 'Serbia and the former Yugoslav Republic of Macedonia were provided humanitarian aid of EUR 1.75 million'.

45 European Council (n 35) 2.

46 The distribution key was based on: a) the size of the population (40\% weighting); b) the total GDP (40\% weighting); c) the average number of asylum applications per one million inhabitants over the period 2010-2014 (10\% weighting); and d) the unemployment rate (10\% weighting). For more information, see Commission, 'On a European resettlement scheme' (Recommendation) C(2015) 3560 final, 3.

47 Conclusions of the Representatives of the Governments of the Member States meeting within the Council on resettling through multilateral and national schemes 20,000 persons in clear need of international protection, 22 July 2015 (OR. en) 11130/15. 
were pledged by Germany $(30,000$ places, as compared to the Union's 20,000 in 2015), $7 \%$ by Sweden, while all other EU countries pledged only $14 \% .{ }^{48}$

Finally, the last international aspect of operationalising the Agenda on Migration is an attempt to more effectively prevent abuses of the European asylum system. In the Agenda, the Commission reported that too many requests were unfounded: in 2014, 55\% of the asylum requests resulted in a negative decision and for some nationalities almost all asylum requests were rejected, hampering the capacity of Member States to provide swift protection to those in need'. ${ }^{49}$ To reinforce the fight against abuses, the Union had to find a way to more easily reject unfounded asylum applications from third country nationals who do not require a visa to come to the EU, and who do not fulfil the conditions to be granted asylum. ${ }^{50}$ Following that reasoning, the Council adopted conclusions on 20 July 2015, ${ }^{51}$ calling upon the Commission to designate certain third countries as 'safe countries of origin'. ${ }^{52}$

Marking countries from where asylum seekers come as 'safe countries of origin would allow swift processing of unfounded asylum applications ${ }^{53}$ and the effective return of those applicants to their countries of origins or some other safe third countries. ${ }^{54}$ This would, in essence, mean that asylum applications of persons coming from third countries designated as safe would be presumed as unfounded, although in each case

\footnotetext{
48 See Commission, 'Relocation and Resettlement Factsheet' < http://ec.europa.eu/dgs/ home-affairs / what-we-do/policies / european-agenda-migration/background-information/ docs/relocation_and_resettlement_factsheet_en.pdf> accessed 30 November 2015.

49 Agenda on Migration (n 6) 12.

50 In other words, they are not being persecuted, subjected to torture or inhuman or degrading treatment or punishment in their countries of origin, nor are they under threat of indiscriminate violence in situations of international or internal armed conflict, within the meaning of Article 9 of Directive 2011/95/EU [2011] OJ L337.

51 Council Conclusions on safe countries of origin, Brussels, 22 July 2015 (OR. en) $11133 / 15$.

52 Directive 2013/32/EU sets out common criteria for the designation of safe third countries of origin by the Member States in its Annex I, which provides the following: 'A country is considered as a safe country of origin where, on the basis of the legal situation, the application of the law within a democratic system and the general political circumstances, it can be shown that there is generally and consistently no persecution as defined in Article 9 of Directive 2011/95/EU2, no torture or inhuman or degrading treatment or punishment and no threat by reason of indiscriminate violence in situations of international or internal armed conflict'.

53 Agenda on Migration (n 6) 13.

54 To support Member States in effectively returning asylum seekers who unfoundedly sought asylum in the EU to their safe countries of origin or other safe third countries, the Commission brought about the following documents: Commission, Recommendation of 1 October 2015 establishing a common 'Return Handbook to be used by Member States' competent authorities when carrying out return-related tasks' C(2015) 6250 final; Commission, 'EU Action Plan on Return' (Communication) COM (2015) 453 final.
} 
the authorities of the Member States would have to allow the individual asylum applicant a chance to prove otherwise.

On 9 September 2015, the Commission set out a Proposal for a regulation establishing an EU common list of safe countries of origin - namely: Albania, Bosnia and Herzegovina, the former Yugoslav Republic of Macedonia, Kosovo, Montenegro, Serbia and Turkey. ${ }^{55}$ This proposal is currently under discussion in the Council.

\subsection{Patching up the EU asylum system}

The final set of measures implemented pursuant to the European Agenda on Migration aims to address the downsides of the current EU legal framework on asylum, as applied on the Union territory in the Member States. As emphasised by the Commission, "the migration crisis ... has revealed much about the structural limitations of EU migration policy and the tools at its disposal'. ${ }^{56}$ A 'clear and well implemented framework of a strong common asylum policy' was outlined as the only way to achieve an efficient asylum system capable of responding to the ongoing refugee crisis of such magnitude. ${ }^{57}$

The first action undertaken by the Commission in this regard was to request from the Member States a more stringent application of the existing legislation - the rules of the Common European Asylum System (CEAS). ${ }^{58}$ Enhancing the process of monitoring Member States' implementation and application of the asylum rules, the Commission, soon after the Agenda on Migration, in September 2015, initiated 37 infringement procedures against 19 Member States for failing to transpose into

\footnotetext{
55 Commission, 'Proposal for a Regulation of the European Parliament and of the Council establishing an EU common list of safe countries of origin for the purposes of Directive 2013/32/EU of the European Parliament and of the Council on common procedures for granting and withdrawing international protection, and amending Directive 2013/32/EU' COM (2015) 452 final.

56 Agenda on Migration (n 6) 6.

57 ibid.

58 The Common European Asylum System (CEAS) is an EU framework of legislative instruments adopted to implement the Geneva Convention Relating to the Status of Refugees (see $\mathrm{n} 7$ ) in the EU legal system. Pursuant to Article 78(2) TFEU, CEAS comprises (a) a uniform status (definition) of asylum and (b) subsidiary protection; (c) a common system of temporary protection for displaced persons in the event of a massive inflow; (d) common procedures for the granting of asylum or subsidiary protection status; (e) criteria and mechanisms for determining which Member State is responsible for considering an application for asylum or subsidiary protection; (f) standards concerning the conditions for the reception of applicants for asylum or subsidiary protection; (g) partnership and cooperation with third countries for the purpose of managing inflows of people applying for asylum or subsidiary or temporary protection. For more information, see Commission, Migration and Home Affairs, 'Common European Asylum System' < http://ec.europa.eu/dgs/home-affairs/whatwe-do/policies/asylum/index_en.htm> accessed 28 December 2015.
} 
their national laws the recently adopted directives ${ }^{59}$ that form part of CEAS. ${ }^{60}$

The second, more substantive Union action in addressing the structural limitations of the asylum legal framework is also the one often praised as the attempt that shows the greatest EU solidarity in responding to the unstoppable inflow of migrants to the frontline Member States. In the Agenda on Migration, the EU was called upon to respond to the unprecedented 'high-volumes of arrivals' to the Union territory by ensuring a 'fair and balanced participation of all Member States' in the common efforts of reception of all those in need of international protection. ${ }^{61}$ The measure envisaged in the Agenda was the ad hoc activation of the Article 78(3) TFEU emergency mechanism for adopting provisional measures for the benefit of the Member State(s) faced with sudden and massive inflows of refugees. In essence, this would introduce exceptions to the applicable rules of the CEAS and relieve the frontline Member States most affected from their Dublin-imposed exclusive responsibility for processing asylum claims of all those who enter into their territory. Through Article 78(3) TFEU, the EU would activate a system of 'relocation' of a certain and predetermined number of refugees from the frontline Member States to other parts of the Union territory. For these purposes, 'relocation' is defined as a transfer of persons who have 'already applied' for international protection from the Member State in charge of examining their application to another EU Member State. ${ }^{62}$

The relevance of this measure must be viewed in the context of the entire Union legal framework for asylum. Pursuant to the default rules of the CEAS Dublin Regulation, ${ }^{63}$ only those Member States where the asylum seekers first enter the EU territory have an obligation to conduct the asylum procedures and remain responsible for providing protection to

59 Directive 2013/32/EU of 26 June 2013 on common procedures for granting and withdrawing international protection [2013] OJ L180/60; Directive 2013/33/EU of 26 June 2013 laying down standards for the reception of applicants for international protection [2013] OJ L180/96.

60 For more information, see ANNEX VII to the Commission Communication on Managing the refugee crisis: immediate operational, budgetary and legal measures under the European Agenda on Migration - Implementing the Common European Asylum System, COM (2015) 490 final/2.

61 Agenda on Migration (n 6) 4: 'Member States' asylum systems today face unprecedented pressure and, with the summer arriving, the flow of people to frontline Member States will continue in the months to come. The EU should not wait until the pressure is intolerable to act: the volumes of arrivals mean that the capacity of local reception and processing facilities is already stretched thin'.

62 Note the difference between the terms 'relocation' and 'resettlement'. While relocation involves transfers of asylum seekers between the EU Member States, resettlement covers persons in clear need of international protection who are transferred from a non-EU third country to an EU Member State.

63 See $\mathrm{n} 12$. 
refugees. ${ }^{64}$ This obligation proves only more significant considering that in the EU there is no 'positive mutual recognition' of approved asylum decisions, meaning that persons who were granted asylum do not have the right to move to or reside in the territories of any other Member State. ${ }^{65}$ Activating the Article 78(3) TFEU emergency mechanism as an exception to the applicable Dublin system would assist the frontline countries, by providing that all other Member States take on part of their burden. ${ }^{66}$ The Member States who receive the relocated asylum seekers would become responsible for examining their asylum applications.

The Agenda on Migration also provides a technical guideline on how to determine which proportionate number of asylum seekers each of the Member States would receive. The proposed 'distribution key' was based on 'objective, quantifiable and verifiable criteria' - namely, the size of the population (40\%), total GDP (40\%), the past numbers of asylum seekers and resettled refugees $(10 \%)$ and the unemployment rate in the state concerned (10\%). ${ }^{67}$ The proposed mechanism aimed not only to ensure a somewhat fair and balanced distribution of the given numbers of asylum seekers within the EU, but also to 'reflect the capacity of the Member States to absorb and integrate refugees'. ${ }^{68}$

So far, the Commission has proposed triggering the Article 78(3) TFEU emergency response system on two occasions. Both times the Council approved, and introduced two relocation schemes for a predetermined number of persons in clear need of international protection for the benefit of the most affected frontline states - Greece and Italy. It is important to emphasise that persons for whom the two relocation systems

\footnotetext{
64 ibid, Arts 7-15. Pursuant to the Dublin Regulation, the default rule is that the 'Member State of first entry' to the Union territory is the only one responsible for processing asylum claims. Certain exceptions to the rules apply, such as instances involving family reunification, protection of minors or the humanitarian will of other Member States to take over the responsibility. For more information on the applicable Dublin rules, see, inter alia, N Bacic, 'Asylum Policy in Europe: The Competences of the European Union and Inefficiency of the Dublin System' [2012] CYELP, 41, 58-59.

65 At least until they receive long term residence after having resided legally and continuously in the territory of a certain Member State for five years. See Directive 2011/51/EU of the European Parliament and of the Council of 11 May 2011 amending Council Directive 2003/109/EC to extend its scope to beneficiaries of international protection [2011] OJ $\mathrm{L} 132 / 1$.

66 Pursuant to Protocols 21 and 22 to the Treaties, the United Kingdom, Ireland and Denmark do not take part in the adoption of measures pursuant to Title V TFEU, such as the present one, unless they notify the Commission or the Member States otherwise.

67 For example, $18.42 \%$ of a given number of asylum seekers would be relocated to Germany, $14.17 \%$ to France, $9.10 \%$ to Spain, while smaller countries such as Croatia would take in $1.73 \%$, or Latvia and Lithuania $1.21 \%$ and $1.16 \%$ respectively. Austria would take in $2.62 \%$, Netherlands $4.35 \%$.

68 See ANNEX I to the Agenda on Migration COM (2015) 240 final.
} 
apply are asylum applicants for whose nationality the average recognition rate of international protection at the EU level is more than $75 \% .{ }^{69}$ Currently, only three nationalities meet the requisite recognition rates: Syrians, Eritreans and Iraqis. ${ }^{70}$

The stories behind introducing these emergency response systems hold many complexities and will thus be further explained only in very general terms.

On 27 May 2015, the Commission issued its first proposal ${ }^{71}$ for the resettlement of 24,000 asylum seekers from Italy and 16,000 from Greece to other Member States, 40,000 of them in total. ${ }^{72}$ The European Council called for the rapid adoption of this measure, inviting all Member States to agree by consensus by the end of July 2015 on the distribution of such persons. ${ }^{73}$ Reaching a decision by unanimity on such a politically sensitive issue for the first time ever in Union history proved to be more difficult than the European Council expected. As a result, the first relocation scheme was introduced by a Council Decision ${ }^{74}$ only on 14 September 2015, almost 4 months after the Commission's initial proposal in May. The decision was reached by consensus.

However, during the summer of 2015 ,

the migratory pressure at the Southern external land and sea borders again sharply increased, and the shift of migration flows has continued from the Central to the East Mediterranean and the Western Balkans route towards Hungary, as a result of the increasing number of migrants arriving in and from Greece. ${ }^{75}$

\footnotetext{
69 Article 3(2) of both Council Decision (EU) 2015/1523 and Council Decision (EU) $2015 / 1601$.

70 See Commission, 'European Solidarity - A Refugee Relocation System' < http:// ec.europa.eu/dgs/home-affairs/what-we-do/policies/european-agenda-migration/background-information/docs/2_eu_solidarity_a_refugee_relocation_system_en.pdf> accessed 30 November 2015.

71 Commission, 'Proposal for a Council Decision establishing provisional measures in the area of international protection for the benefit of Italy and of Greece' COM (2015) 286 final 2015/125 (NLE).

72 This final number was proposed by the Commission based on the Eurostat and Frontex data on the number of persons who had applied for asylum in Italy or Greece in 2014 and in the first quarter of 2015. See Council Decision (n 71) recitals 10 and 11.

73 European Council meeting (n 35) para 4(b).

74 Council Decision (EU) 2015/1523 of 14 September 2015 establishing provisional measures in the area of international protection for the benefit of Italy and of Greece [2015] OJ L239/146.

75 Commission, 'Proposal for a Council Decision establishing provisional measures in the area of international protection for the benefit of Italy, Greece and Hungary' COM (2015) 451 final 2015/0209 (NLE) recital 11.
} 
In the first eight months of 2015, approximately 116,000 irregular migrants arrived in Italy (10,000 of them registered), 211,000 in Greece (28,000 registered) and 145,000 in Hungary through the Western Balkans route (3,000 registered). Between January and July 2015, these three countries received 39,000, 8,000, and 98,000 asylum applications, respectively. ${ }^{76}$ By the end of summer 2015, Europe was facing what was amounting to around two-thirds of a million asylum seekers and irregular migrants. ${ }^{77}$ In that context, just 40,000 relocations proposed by the Commission in the first emergency relocation scheme seems marginal.

On 9 September 2015, the Commission came out with its second proposal $^{78}$ for the relocation of another 120,000 asylum seekers from Italy, Greece and Hungary ${ }^{79}$ - in addition to those 40,000 relocations already proposed. However, relying on the lessons learned from the 4-month political fight for consensus on the first proposal for just one-third of the relocations then being proposed, the Council implemented the second emergency decision ${ }^{80}$ only 12 days after the proposal. The decision was made by a qualified majority vote, outvoting Hungary, the Czech Republic, Romania, and Slovakia. ${ }^{81}$ Interestingly enough, Hungary even rejected having the relocations take place for its own benefit, which is why the final decision designated the Hungarian numbers for relocations to Italy and Greece proportionally. ${ }^{82}$

The more pressing issue of the second relocation decision, however, was the qualified majority by which it was passed in the Council. The legislative provision upon which the decision was based is the aforementioned Article 78(3) TFEU, which merely states that the Council may adopt emergency measures, after consulting the European Parliament. Given the Article's legal setting in Title V of the TFEU, the default rules should apply whereby the Council votes by a qualified majority unless explicitly stated otherwise. ${ }^{83}$ However, not all relevant legal actors seem to agree on that point, which is why the outvoted Slovakia and Hungary

\footnotetext{
76 ibid, recital 12 .

77 Irregular migrants in most cases are indeed refugees who would qualify for asylum, but did not want to apply for asylum in the frontline Member States, thus the term 'irregular'.

78 European Commission, 'Proposal for a Council Decision establishing provisional measures in the area of international protection for the benefit of Italy, Greece and Hungary' COM (2015) 451 final 2015/0209 (NLE).

79 15,600 from Italy, 50,400 from Greece, 54,000 from Hungary.

80 Council Decision (EU) 2015/1601 of 22 September 2015 establishing provisional measures in the area of international protection for the benefit of Italy and Greece [2015] OJ L248/80.

81 Finland abstained.

82 Council Decision (n 80) Art 4(2).

83 See Articles 293-296 TFEU.
} 
both announced ${ }^{84}$ that they would file an action for the annulment ${ }^{85}$ of the Decision with the Court of Justice of the EU. ${ }^{86}$

The prospect of the envisaged innovation of 'relocations' was seen as bringing much needed solidarity to the existing Dublin system. This encouraged the Commission also to propose making the emergency relocation mechanism originally envisaged under Article 78(3) TFEU a lasting solution to the EU's asylum policy problems. 'The EU needs a permanent system for sharing the responsibility for large numbers of refugees and asylum seekers among Member States' ${ }^{87}$ In its proposal ${ }^{88}$ of 9 September 2015 (the same day the second emergency relocation was proposed), the Commission requested that the Parliament and the Council amend the existing Dublin Regulation by introducing into it a permanent crisis 'relocation' mechanism as an exception to the otherwise applicable Dublin rules. The proposal would introduce the very same mechanism of relocation that was triggered under the emergency Article 78(3) TFEU into the existing Dublin framework, thus making it an integral part of the Common European Asylum System, and not just an addition thereto under the Treaties.

The idea was that once the emergency exception was introduced in the Dublin Regulation, the Commission itself would have the power to activate it. As proposed, the relocation regime would be triggered automatically for the benefit of a certain Member State when, based on substantiated information gathered by EASO and Frontex, the Commission establishes that this State is

confronted with a crisis situation jeopardizing the application of the Dublin Regulation due to extreme pressure characterised by a large and disproportionate inflow of third-country nationals or

\footnotetext{
84 See E Zalan, 'Hungary To Challenge Refugee Quotas In EU Court' (EUobserver, 18 November 2015) <https://euobserver.com/migration/131158> accessed 28 December 2015 and A Rettman, 'Slovakia Filing Case Against EU Migrant Relocation' (EUobserver, 30 September 2015). <https://euobserver.com/justice/130499> accessed 28 December 2015.

85 See Article 263 TFEU.

86 For a more detailed analysis of the legality of the qualified majority vote for the second relocation decision, see S Peers, 'Relocation of Asylum-Seekers in the EU: Law and Policy' (EU Law Analysis, 24 September 2015) <http: / / eulawanalysis.blogspot.hr/2015/09/relocationof-asylum-seekers-in-eu-law.html?utm_source=feedburner\&utm_medium=email\&utm_ca mpaign=Feed:+EuLawAnalysis+(EU+Law+Analysis $)>$ accessed 28 December 2015.

87 Agenda on Migration (n 6) 4.

88 Commission, 'Proposal for a Regulation of the European Parliament and of the Council establishing a crisis relocation mechanism and amending Regulation (EU) No 604/2013 of the European Parliament and of the Council of 26 June 2013 establishing the criteria and mechanisms for determining the Member State responsible for examining an application for international protection lodged in one of the Member States by a third country national or a stateless person' COM (2015) 450 final 2015/0208 (COD)
} 
stateless persons, which places significant demands on its asylum system. ${ }^{89}$

Amending the Dublin Regulations under Article 78(2) TFEU falls within the Title $\mathrm{V}$ general rule on an ordinary legislative procedure, ${ }^{90}$ whereby the Council votes by a qualified majority, co-legislating with the European Parliament. Introducing a relocation system under this concept would mean bypassing the problems of the kind witnessed with outvoted Member States under Article 78(3) TFEU by formally incorporating the relocation mechanism within the Dublin Regulation, which can undoubtedly be done by a qualified majority.

In other words, if the Union wanted to initiate a relocation scheme, it would no longer have to pass each individual decision through the Council. Once the relocation scheme entered into the Dublin Regulation through an amendment that was passed in an ordinary legislative procedure, it would be solely for the Commission to determine, based on objective criteria, whether there was a crisis situation that merited activating the relocation scheme.

Finally, the last piece of Commission action pursuant to the Agenda on Migration was to undertake a substantive evaluation of the Dublin system in 2016. In doing so, the Agenda called for 'drawing on the experience from the relocation and resettlement mechanisms which would help to determine whether a revision of the legal parameters of Dublin will be needed to achieve a fairer distribution of asylum seekers in Europe'. ${ }^{91}$

\section{Legal setting of the Agenda measures: The Dublin system as a de- fault}

The previous sections, dissecting the measures that were envisaged in the Agenda on Migration and later on operationalised, support the conclusion that all EU actions in responding to the refugee crisis were either answers to the problems already occurring on the Union's territory or at its borders, or efforts to prevent the refugee crisis reaching the Union in the first place.

For example, the Mediterranean operations and the strengthening of external border controls, alongside the humanitarian approach, aim at the effective management of migration flows onto the Union territory. The international efforts of the Union in offering financial support to third countries hosting refugees undoubtedly aims at ensuring that part of the refugee crisis remains someone else's concern. The resettlement of

\footnotetext{
ibid, Article 33a (1).

90 Article 294 TFEU.

91 Agenda on Migration (n 6) 13.
} 
20,000 refugees could be seen as a way of giving something in return to those third countries for keeping a great deal of the problem outside the Union borders. Yet, the number of 20,000 seems quite marginal as compared to the existing number of displaced persons, especially following the Syrian civil war. UNHCR estimates that, at the present moment, more than 4 million Syrian refugees are displaced in Turkey and the Middle East. ${ }^{92}$

The final set of measures, those for addressing the proven drawbacks of the Union legal framework, likewise present responses to the refugee crisis that had already started raging on the Union territory. Activating the emergency exception to the CEAS framework under Article 78(3) TFEU in itself shows that the existing legal system was not functioning properly from the very beginning. The Union policy choice of introducing innovations to the system was presented as the only way to save the system from falling apart. The 'relocation' scheme was precisely that type of innovation to ease the pressure on the frontline Member States which would otherwise be held responsible for the refugees through the Dublin rules. Under this concept, refugees who had already sought asylum in the frontline Member States, adhering to the existing Dublin regime, would then be relocated to other Member States who would take over the obligation of processing their asylum claims. The core problem of the Union crisis management technique lies precisely at this point: all measures the Union has taken presuppose that the Dublin system is a default rule to which all the actors comply.

As previously stated, the Dublin system is based on the 'country of first entry' concept, making the frontline Member States, in general, the ones responsible for processing asylum applications and providing international protection. However, this system for allocating Member States' responsibilities to examine asylum applications has long proven itself to be inefficient. Instead of sharing responsibilities, the system has resulted in shifting the burden onto the Member States on the EU's external borders. The pressure placed on these states resulted in extensive litigation before both the Strasbourg ${ }^{93}$ and the Luxembourg ${ }^{94}$ courts a few years ago, before anyone could foresee a refugee crisis of the present magnitude. In essence, both of these cases ended by concluding that the stringent imposition of the Dublin rules on an over-stretched Greece

\footnotetext{
92 See UNHCR, 'Syria Regional Refugee Response' < http:/ / data.unhcr.org/syrianrefugees / regional.php> accessed 30 November 2015. Turkey hosts more than 2.1 million Syrian refugees, while 1 million of them are in Lebanon and 600,000 in Jordan.

93 MSS $v$ Belgium and Greece App no 30696/09 (ECtHR, 21 January 2011).

94 Joined Cases C-411/10 and C-493/10 N S v Secretary of State for the Home Department and $M E$ and others $v$ Refugee Applications Commissioner, Minister for Justice, Equality and Law Reform ECLI:EU:C:2011:865.
} 
violated refugees' fundamental rights not to be subjected to inhuman or degrading treatment. ${ }^{95}$ In other words, the Dublin system proved to be inefficient even in situations verging on the normal. ${ }^{96}$

Even the Commission emphasised in the Agenda on Migration that 'the Dublin system is not working as it should. In 2014, five Member States dealt with $72 \%$ of all asylum applications EU-wide'. ${ }^{97}$

At this point, it must be clearly emphasised that the Dublin system was not envisaged to function in emergency situations. It proved itself not to be able to function under normal conditions, let alone in the present refugee crisis. 'When the Dublin system was designed, Europe was at a different stage of cooperation in the field of asylum. The inflows it was facing were of a different nature and scale'. ${ }^{98}$

Still, all Union measures taken pursuant to the Agenda presuppose that the Dublin system is a default rule to which all the actors comply, without substantively shifting Dublin's most problematic paradigm. This mainly refers to the 'relocation mechanism' both as an 'emergency' exception to CEAS under Article 78(3) TEFU and as an announced 'permanent' solution for crisis situations introduced by amendments to the Dublin Regulation.

The author's strong position is that no emergency situation and refugee crisis could ever be resolved by reliance on the Dublin system and by introducing amendments thereto, whatever the scope and effect of those amendments. There are two reasons for this, which are outlined below.

Firstly, because Dublin is based on the 'country of first entry' concept, no exception to that system can reverse its underlying rule that frontline Member States are always the ones 'initially' responsible for asylum seekers. It must be reiterated that this core principle of Dublin was found to violate refugees' fundamental rights even before the 2015 crisis. In the Agenda on Migration, the Commission nonetheless provides that 'the EU can provide further assistance, but the rules need to be applied in full. Member States are responsible for applying the Dublin system'. ${ }^{99}$

This statement bluntly proves that the Commission insists on applying the Dublin Regulation as a default rule (which none of the Member States currently adheres to in practice, as will be assessed later on). It

\footnotetext{
95 Article 3 ECHR, Articles 4 and 19 Charter; non-refoulement principle.

96 For a more detailed analysis of the pre-crisis inefficiency and non-application of the Dublin system, see N Bacic, 'Asylum Policy in Europe: The Competences of the European Union and Inefficiency of the Dublin System' [2012] CYELP, 41, 62-64.

97 Agenda on Migration (n 6) 13.

98 ibid.

99 Agenda on Migration (n 6) 13.
} 
also shows that the Commission sees all the relocation measures undertaken as 'assistance' provided to the 'otherwise responsible' Member States by enabling mechanisms of relieving their pressure. However, insisting on adherence to the Dublin Regulation must be viewed in a broader context than the Commission seems to suggest. In a situation where frontline Member States are being confronted with mass inflows of refugees, insisting on their initial responsibility of which the other Member States will relieve them 'in a spirit of solidarity' (pursuant to the relocation scheme) brings into question the entire 'fair sharing of responsibility' concept underlying the Union common policy on asylum. ${ }^{100}$

Secondly, introducing exceptions to the Dublin Regulation by means of surreptitiously placing within it a relocation scheme presupposes that Dublin is a default rule to which all the relevant actors comply. Under the framework of 'relocations', only refugees 'who already sought asylum in the frontline Member States' adhering to the existing Dublin regime would be relocated to other Member States who then take over the obligation of processing their asylum claims. However, this presumption must again be placed in a real-life context where most refugees, especially as witnessed in the case of Croatia, do not want to seek asylum in frontline Member States. ${ }^{101}$ They do not submit asylum applications in the Member State in which they should pursuant to the Dublin rules which, formally, do not provide them with the right to choose a Member State of their preference. ${ }^{102}$ The only real-life option is to let them

\footnotetext{
100 See Article 80 TFEU. It should be acknowledged that a substantive shift of Dublin's underlying principle (on initial responsibility of frontline Member States) could in theory bring about acceptable results for handling a refugee crisis. However, this substantive shift would have to distinguish a default system in times of crisis from a default system in normal situations. When faced with an emergency, the default rule would have to be the initial responsibility of all Member States in a spirit of solidarity. The current proposals for the Dublin amendments still fail to do so and insist on introducing exceptions to the generally applicable rules on frontline Member States' initial responsibility. Those frontline Member States are then aided by transferring their responsibility to other Member States. In other words, all proposed amendments still presuppose that crisis measures are only an exception to the default Dublin rules. This initial responsibility of frontline Member States is precisely what fosters the mutual feeling of distrust and makes it easy to oppose solidarity, which in practice should occur once the responsibilities are taken over by other Member States. There is no other way to achieve true solidarity in times of crisis unless all Member States are $a b$ initio legally responsible, thus being placed at the same starting point.

${ }^{101}$ Based on unpublished information available to the author, fewer than 20 people have sought asylum in Croatia since the redirection of the Western Balkans route to this country on 16 September 2015. Since that day, more than 465,000 refugees have crossed through Croatia on their path to other EU Member States, primarily Germany, Austria or Sweden. See Ministry of the Interior of the Republic of Croatia, 'Information on Accepting and Accommodating Migrants in Croatia'<http://www.mup.hr/219671.aspx> accessed 5 December 2015

102 The Dublin Regulation does not impose an obligation on refugees to apply for asylum in the Member State of their entry into Union territory per se. However, Member States where they seek asylum may send them back to other Member States through which they entered
} 
through, disregarding the Dublin legal framework. The alternative is to violate the Geneva Convention and the Member States' international and humanitarian obligations. In other words, this alternative is refoulement and violation of refugees' human rights as underlying values of the Union legal order protected by the Charter, as well as the European Convention of Human Rights. So far, few Member States have chosen this alternative in the name of salvaging the Dublin system.

\section{Was there an alternative? The crisis management system within the CEAS}

The author submits that the Union's policy choice of saving the entire Common European Asylum System by introducing the exceptions to the default Dublin rule on frontline Member States' responsibility presents an 'intentional' misconception of the entire system. The crux of refugee crisis management problems breaks down precisely at this point. Namely, the Dublin Regulation is not the only concept of allocating Member States' responsibility for processing asylum claims within the existing framework of the CEAS.

In addition to the Dublin system, the CEAS provides for another concept of determining the responsible Member State - the one provided for by the Temporary Protection Directive. ${ }^{103}$ Unlike the Dublin Regulation, the system of temporary protection provides that, in crisis situations, all the Member States share responsibility for protecting refugees on the basis of solidarity. ${ }^{104}$ Moreover, this system was specifically designed as a scheme of offering international protection in cases of 'mass influx of refugees' onto the Union territory, which is the underlying reason for its existence. ${ }^{105}$

The Temporary Protection Directive was introduced into the Common European Asylum System back in 2001, following the experiences of the EU Member States dealing with unprecedented flows of Kosovar refugees displaced by the conflict in former Yugoslavia. ${ }^{106}$ In essence, the

its territory illegally. This applies equally to all Member States where refugees resided illegally, resulting in transfers all the way back to the Member State of first entry into the Union territory, as a chain reaction. See Article 13 of the Dublin Regulation, as well as Directive 2008/115/EC on common standards and procedures in Member States for returning illegally staying third-country nationals [2008] OJ L348/98.

103 Council Directive 2001/55/EC of 20 July 2001 on minimum standards for giving temporary protection in the event of a mass influx of displaced persons and on measures promoting a balance of efforts between Member States in receiving such persons and bearing the consequences thereof [2001] OJ L212/12 (hereinafter: Temporary Protection Directive).

104 ibid, recitals 7 and 9, Article 25(1).

105 ibid, recital 2.

106 ibid, recitals 3-9. 
Temporary Protection Directive codified into the Union legal framework the rules of coordinated action by the EU Member States in the humanitarian evacuation of Kosovar refugees to temporary safety. ${ }^{107}$

The temporary protection system, as implemented in the Union legal order, is not a new concept on the global scale. An initially envisaged variation thereof was first mentioned in the 1969 African refugee convention. ${ }^{108}$ It was also "promoted during mass flows from Southeast Asia and vigorously debated in the context of flight from Central American civil wars in the 1980s'. ${ }^{109}$ The first coherent structure of the temporary protection scheme was described in the UNHCR's 1994 Report on International Protection. ${ }^{110}$ The general purpose of this legal instrument was to provide the international community with a tangible solution to dealing with sudden mass influxes of refugees. It is an 'emergency response to the large-scale movement of asylum-seekers, providing immediate protection from refoulement and basic minimum treatment'. ${ }^{11}$

In the EU context, this system was designed in the following manner.

Article 1.1(a) of the Directive defines 'temporary protection' as a procedure of exceptional character to provide, in the event of a mass influx or imminent mass influx, all displaced persons with immediate and temporary protection, in particular if there is also a risk that the asylum system will be unable to process this influx without adverse effects for its efficient operation. In that sense, temporary protection is an entirely different status from asylum, an entirely different mode of international protection.

The essential characteristic of this system may be seen from the following fact. General asylum procedures under CEAS grant protection to specific individuals who meet the necessary requirements to be granted asylum. ${ }^{12}$ On the other hand, temporary protection offers international

107 See Council Resolution on burden-sharing with regard to the admission and residence of displaced persons on a temporary basis [1996] OJ C262/1; Action Plan of the Council and the Commission [1999] OJ C19/1.

108 Organization of African Unity, Convention on the Specific Aspects of Refugee Problems in Africa, opened for signature 10 September 1969, 1000 UNTS 46 (entered into force 20 June 1974).

109 J Fitzpatrick, 'Temporary Protection of Refugees: Elements of a Formalized Regime' (2000) 94(2) American Journal of International Law 279, 279.

${ }^{110}$ UNHCR, Note on International Protection, UN Doc A/AC96/830 (1994) 23.

${ }^{111}$ UN High Commissioner for Refugees (UNHCR) 'Guidelines on Temporary Protection or Stay Arrangements' (February 2014) <http://www.unhcr.org/542e99fd9.pdf> accessed 5 December 2015

112 See Directive 2011/95/EU of the European Parliament and of the Council of 13 December 2011 on standards for the qualification of third-country nationals or stateless persons as beneficiaries of international protection, for a uniform status for refugees or for persons eligible for subsidiary protection, and for the content of the protection granted [2011] OJ L337/9; and Directive 2013/32/EU of the European Parliament and of the Council of 
protection to groups, that is, all displaced persons coming to the Union territory in a mass influx, those who are unable to return to their country of origin in safe and durable conditions because of the situation prevailing in that country (for example, because they fled areas of armed conflict or endemic violence ${ }^{113}$ or because they were subject to systematic or generalised violations of their human rights). ${ }^{114}$

In procedural terms, the temporary protection mechanism is activated in a special simplified legislative procedure - when the Council adopts a Decision by a qualified majority, on a proposal from the Commission, submitted on the Commission's own behalf or following a request made by any of the Member States. ${ }^{115}$ The European Parliament does not participate in the decision-making process, but is merely informed of the Council Decision. ${ }^{116}$

Based on the Commission's assessment of the emergency situation and the scale of arrivals into the Union, the Council Decision would automatically designate a group of beneficiaries of temporary protection (those who satisfy the Directive requirements - they fled armed conflict, endemic violence or systematic and generalised violations of their human rights). This would apply likewise when the beneficiary group spontaneously arrives in mass numbers onto the Union borders, but also in the case of their assisted evacuation into the EU from endangered areas in third countries. ${ }^{117}$ The Council Decision would furthermore specify the date on which the temporary protection would take effect, but would also pre-designate the quotas - in figures or in general terms - for the reception capacities of the Member States. The quotas would be determined in the Council Decision based on the information received from the Member States on their reception capacities. The Council would also consider the information received from the Commission, other Union institutions, the UNHCR and other relevant international organisations. ${ }^{118}$

Pursuant to the Council Decision, all individuals belonging to a group of designated beneficiaries (for example, all Syrian refugees fleeing from armed conflict in their country of origin) would automatically be granted temporary protection status as soon they reach Union borders,

26 June 2013 on common procedures for granting and withdrawing international protection [2013] OJ L180/60.

${ }^{113}$ At this point, the author would just like to note the resemblance of this definition with the mass displacement of Syrian nationals in the ongoing refugee crisis.

114 Temporary Protection Directive (n 103) Art 1.1(c).

115 ibid, Art 5(1).

116 ibid, Art 5(5).

$117 \mathrm{ibid}$, Article 2.1(d). Also note that assisted evacuation into the EU would be a concept similar to the 'resettlement' of displaced persons.

118 ibid, Article 5(3). 
without any need for conducting individual and detailed assessments impossible to perform in the context of a mass influx. This, of course, is without prejudice to the Member States being allowed to exclude a person from entry into their territory and from temporary protection for public security reasons if there are serious grounds for regarding that this person committed a serious crime. ${ }^{119}$ Beneficiaries of the protection would then, subject to their own consent, be transferred from the Member State in which they crossed the Union border into one of the other EU Member States, pursuant to a proportionate system of transfers to all Member States in line with the quotas designated in the Council Decision. All transfers would take place through administrative and operative cooperation between the national authorities of the Member States. ${ }^{120}$

As previously stated, the status of temporary protection would be granted to all displaced persons as soon as they reach Union territory. This would mean that the Member State of entry would instantly issue for them a short-term residence permit, making their stay in the Union territory automatically legal. Once displaced persons are transferred to the Member State of their destination, they would be issued with a new residence permit from that Member State. In addition to the residence permit, persons under temporary protection would automatically receive an entire set of rights that are, however, of a lesser scope than provided for by virtue of the asylum status. These rights would include: limited access to employment, ${ }^{121}$ access to suitable accommodation and, if necessary, the means to obtain housing, emergency health care and essential treatment of illness, medical assistance to persons with special needs, access to education for minors, representation of unaccompanied minors, and a limited right ${ }^{122}$ to family reunification. ${ }^{123}$

The system of protection provided to displaced persons pursuant to this Directive, according to its wording, would last only for a limited period - three years at the maximum. The duration of the temporary protection scheme, under which displaced persons are protected, as well as accepted into the Union territory, would initially be one year. This period could be extended automatically by six monthly periods for a maximum

\footnotetext{
${ }^{119}$ For more information on exclusions based on public security, see the Temporary Protection Directive (n 103), Article 28

120 See the Temporary Protection Directive (n 103) Art 26. Coordinated transfers under this system seem fairly interesting in the context of the current refugee crisis - taking into account the Western Balkans route often subjecting refugees to inhumane conditions on their path to reach Germany.

${ }^{121}$ Member States could give priority to EU and EEA citizens, as well as legally resident third country nationals who receive unemployment benefits.

${ }^{122}$ Spouses, partners, minor children and dependants (close family members who lived in a family unit).

${ }^{123}$ See the Temporary Protection Directive (n 103) Arts 8-16.
} 
of one year. If, however, the reasons for temporary protection persist, the Council may again decide by a qualified majority to extend that temporary protection by up to one year. ${ }^{124}$

The most significant aspect of the EU temporary protection scheme lies in the fact that temporary protection does not prejudice recognition of refugee status under the Qualification Directive (and the Geneva Convention) - meaning that individual persons enjoying temporary protection must be able at all times to lodge an application for asylum as a more permanent status of international protection. ${ }^{125}$

Furthermore, and even more importantly for the purposes of this article - the Member State that is ab initio responsible for examining asylum claims of persons under temporary protection is solely the Member State to which they were transferred pursuant to the quota system of the temporary protection scheme, and not the Member State in which they took their first step onto Union territory. ${ }^{126}$ The importance of this provision cannot be overstated, as it establishes within the existing framework of the CEAS a system of determining the Member States responsible for examining asylum applications that exists in addition to the Dublin Regulation. Moreover, this system of Member State responsibility for refugees, unlike the Dublin Regulation, is per se designated for crisis situations. By introducing the Temporary Protection Directive, the Union itself admitted it is necessary to establish a mechanism for events of mass influx of displaced persons that promotes a balance of efforts between the Member States in receiving and bearing the consequences of receiving such persons - 'for reasons of effectiveness, coherence and solidarity and in order, in particular, to avert the risk of secondary movements'. ${ }^{127}$

Temporary protection, along with the limited rights attached to that status, in itself is indeed a lesser degree of protection than what is currently required by international refugee law (namely, by the Geneva Convention which binds all the EU Member States). ${ }^{128}$ However, no such concerns of possible violations of the Geneva obligations arise in the EU context - precisely because temporary protection rules are instantly paired with a provision that allows all persons under temporary protection to seek asylum. This is a provision that, moreover, introduces a mechanism of true solidarity in sharing responsibility for processing asylum applications among all the Member States.

\footnotetext{
124 ibid, Art 4.

125 ibid, Arts 3(1) and 17(1).

126 ibid, Art 18.

127 ibid, recitals 8 and 9

${ }^{128}$ M Bulterman, W van Genugten (eds), Netherlands Yearbook of International Law 2013: Crisis and International Law: Decoy or Catalyst? (TMC Asser Press 2014) 73.
} 
In other words, this type of protection allows EU Member States 'to offer temporary protection to groups, and deal with the individual cases later'. In this sense, temporary protection allows EU Member States to efficiently deal with mass inflows of refugees. 'While [asylum] law deals with refugees individually, temporary protection would allow [dealing] with a refugee crisis ... Once a mass influx of refugees subsides, [Member States may return] from temporary to "normal" refugee protection'. ${ }^{129}$

Considering all the aforementioned, one might doubtlessly say that temporary protection paired with the relocation of asylum responsibility in true solidarity is, by its very definition, 'a Dublin alternative'. Precisely this point makes the Temporary Protection Directive the EU's strongest weapon in the arsenal of legal measures available for dealing with a refugee crisis.

However, as all seemingly perfect measures must have a catch, indeed so does the Temporary Protection Directive. From the provisions of the Directive, it cannot be ascertained beyond doubt that the Council can, as a matter of law, impose quotas on Member States who refuse to take part in the temporary protection scheme - those who were outvoted in the qualified majority decision-making process. In the real-life context where certain Member States challenge the imposition of quotas even in a small-scale relocation system, ${ }^{130}$ this instantly poses a pressing question.

The answer, however, is not that simple and raises complicated issues, such as EU competences, subsidiarity, harmonisation, literal and teleological interpretation of the Directive and its proposals, the travaux préparatoires, the legal setting within the Treaties, etc - matters which would ultimately be for the Court of Justice to decide. That is why the author will address these issues in the simplest terms necessary for the current discussion.

The problem arises because the Directive does not explicitly refer to situations in which one of the Member States refuses to accept quotas, or denies the Council access to information on its reception capacities. It simply states that 'Member States shall receive persons who are eligible for temporary protection in a spirit of Community solidarity and shall indicate [to the Council] - in figures or in general terms - their capacity to receive such persons'. ${ }^{131}$ These capacity indications would then be included in the Council decision. ${ }^{132}$ However, capacity figures subjectively provided for by the Member States are not the only ones included in the

\footnotetext{
129 ibid.

${ }^{130}$ Referring to the announcements of Hungary and Slovakia to challenge quotas for relocation imposed through a Council decision brought by qualified majority.

131 Temporary Protection Directive (n 103) Art 25.

132 ibid, Art 5.3(c).
} 
Council Decision. The Council Decision must also take into account the objective information received from UNHCR and other relevant international organisations, but also the information received from the Commission itself. ${ }^{133}$ This could be interpreted as to mean that there is nothing to prevent the Council from introducing quotas that differ from the reception capacity communicated by the Member States.

The only startling term in the Directive that would suggest otherwise is Article 18 thereof, stating that a Member State responsible for asylum applications of persons enjoying temporary protection is the Member State that accepted the transfer onto its territory. At first sight, this seems to indicate that Member States have the right not to accept the transfers. However, it says nothing decisive on the issue of the Council imposing initial quotas, irrespective of the latter transfers. Nonetheless, should this issue occur, the author would not hesitate to claim ${ }^{134}$ that quotas (defined as indicators of Member States' capacity) can indeed be imposed on those Member States, as a matter of law. ${ }^{135}$

The arguments for proving this claim could be formed as follows. It must be recalled that the Temporary Protection Directive is a full-fledged part of Title V TFEU and the harmonised Common European Asylum System. Within Title V, all measures are decided by default in an ordinary legislative procedure in which certain Member States may be outvoted. ${ }^{136}$ Moreover, the Council Decision of activating the temporary protection scheme is in the very wording of the Directive made by a 'qualified majority'. The Council Decision is also stated to have the effect of introducing

\footnotetext{
133 The Commission's assessment for determining the quotas for allocation could undoubtedly be based on objective information gathered from other Union institutions, such as Frontex, EASO and Eurostat, as was the case with the distribution key set for the relocation scheme mechanism under Article 78(3) TFEU.

${ }^{134}$ Not all authors would agree on this point. See, for example, M Garlick and J van Selm, 'From Commitment to Practice: The EU Response' (2012) 39 Forced Migration Review 20 <http://www.fmreview.org/north-africa/garlick-vanselm.html\#sthash.iewe7fJK.dpuf> accessed 30 December 2015: 'The Directive contains no binding obligation for Member States to receive people admitted under temporary protection to other States'.

135 The question remains, however, on how quotas would be imposed on Member States who refuse to accept the transfers in practice - in other words, would Member States accept those transfers (even if they have the right not to accept)? Yet again, this is a very similar issue to the one that currently emerges with imposing quotas on Member States in the system of relocations under Article 78(3) TFEU. The problem could hypothetically be resolved by the Commission's recourse to infringement proceedings against the relevant Member State, pursuant to Article 258 TFEU.

136 This would also mean that, even if the Temporary Protection Directive were to be interpreted as meaning that the Council cannot impose quotas on the Member States, the Directive could easily be amended so as to explicitly specify the contrary. Amendments are introduced in an ordinary legislative procedure with the Council's qualified majority vote. The same was done with the relocation scheme being proposed as an amendment to the Dublin Regulation.
} 
temporary protection for displaced persons in all the Member States. ${ }^{137}$ Furthermore, when a sudden and massive influx into the Union territory exceeds the reception capacities indicated by the Member States themselves, the Council is obliged, as a matter of urgency, to examine the situation and take appropriate action. ${ }^{138}$ This would mean that, if the Member States did not wish to proceed with quotas on a voluntary basis, the Council is called upon to act.

The aforementioned arguments could support the conclusion that the temporary protection mechanism may indeed be legally imposed on all the Member States. This is also strengthened by the fact that the preamble of the Directive defines a mechanism of temporary protection in the spirit of solidarity as the 'actual reception' of displaced persons in the Member States - which is specifically relevant because the initial

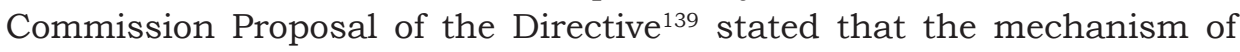
solidarity entails reception of displaced persons 'on the basis of a voluntary action by the receiving Member States'. ${ }^{140}$ There must have been a reason why this underlying explanation of the Directive was amended in the course of the legislative procedure. ${ }^{141}$ The final text of the Directive was similarly amended on various other instances, as compared to what the Commission initially intended - removing all referrals to the Member

\footnotetext{
137 Temporary Protection Directive (n 103) Art 5(1). It is important to note that the Directive applies to all Member States except Denmark. Even the UK and Ireland, generally excluded from Title V measures pursuant to a Protocol annexed to the Treaties, gave notice of their wish to take part in the adoption and application of this Directive.

138 ibid, Art 25(3). Admittedly, appropriate action is stated to include (though not exclusively) recommending additional support for the affected Member States. However, nothing in the Article precluded Council action of a different kind, such as reviewing the Decision initially introducing temporary protection. In this context, it is also interesting to note that the initial Commission proposal of the Temporary Protection Directive did not include urgent and appropriate actions of the Council if the capacities designated by the Member States prove to be insufficient for handling the massive influx. Even more interestingly, the initial Directive proposal did not prescribe that the Council Decision must, in addition to the information received from the Member States, also take into account information provided for by the Commission, UNHCR and other relevant international organisations. Quite the contrary, the Proposal, as compared to the final text of the Directive, went more clearly in favour of the Member States - stating that only declarations by the Member States on their reception capacities would be included in the Council Decision. There must be a reason why the initial proposal was amended as to leave more leeway for the Council.

139 Proposal for a Council Directive on minimum standards for giving temporary protection in the event of a mass influx of displaced persons and on measures promoting a balance of efforts between Member States in receiving such persons and bearing the consequences thereof /* COM/2000/0303 final - CNS 2000/0127 [2000] OJ C311 E.

140 Temporary Protection Directive (n 103), recital 20 (emphasis added).

${ }^{141}$ An explanation of the Commission's resilience in proposing a stronger piece of legislation might be found in the Explanatory Memorandum of the Proposal (para 6.1): 'The Commission considers that the question of physical distribution must be settled by the Community legislation ... But only a physical distribution based on the voluntary action of the Member States will found a consensus in the EU'.
} 
States' voluntary and decisive role in the application of the scheme. ${ }^{142}$ The Union legislator obviously aimed at leaving this matter ambiguous, with a certain agenda in mind. Although the introduced Proposal amendments do not provide a definitive answer, they give the benefit of the doubt to the fact that quotas could indeed be imposed. The textual ambiguity was most likely left there for a reason, so as to provide more leeway for the Council and the Commission in the expected political struggles with Member States when pushing for the activation of the temporary protection mechanism.

Nonetheless, even if this entire issue is set aside, and even if the temporary protection scheme were based on the Member States' voluntary action, this in no way undermines the importance of the Temporary Protection Directive and its system of solidarity in determining the Member States responsible for asylum seekers. In the worst-case scenario, where this scheme were activated for 23 or even 15 out of 27 Member States, ${ }^{143}$ all the benefits of temporary protection would still outweigh all the core drawbacks of the current EU crisis management technique - insisting on the Dublin system as the default rule and introducing exceptions thereto in order to prevent the system from completely falling apart.

Firstly, unlike the Dublin exceptions where the primary responsibility for asylum seekers still stays on the frontline Member States but is then taken over by other Member States, the temporary protection system designated all (participating) Member States ab initio responsible for asylum seekers. Apart from taking care of the current political struggles of the frontline Member States to prevent returns of asylum seekers onto their territory by invoking Dublin rules, this system would introduce true crisis solidarity within the full meaning of that word.

Secondly, temporary protection would also give immediate status to all those displaced persons arriving on Union territory without imposing on them the Dublin obligation of applying for asylum in the frontline Member State - an obligation that is, under the currently applied relocation mechanisms, a precondition for those persons to be relocated to other Member States. It would also allow the Union to be realistic in terms of numbers.

In the first eight months of 2015, approximately 76 out of 116,000 refugees who arrived in Italy did not seek asylum in that country. For Greece, the situation is even worse - asylum was sought by only 8 out of 211,000 refugees. ${ }^{144}$ And all these shocking numbers do not include, for

\footnotetext{
${ }^{142}$ See also $n 138$.

${ }^{143}$ The Directive applies to all Member States except Denmark. See n 137.

${ }^{144}$ Commission, 'Proposal for a Council Decision establishing provisional measures in the area of international protection for the benefit of Italy, Greece and Hungary' COM (2015) 451 final 2015/0209 (NLE) recital 12.
} 
the most part, the statistics of the Western Balkans route from the second part of 2015 - where 145,000 refugees passed through Hungary ${ }^{145}$ and 465,000 through Croatia. ${ }^{146}$ Furthermore, only Germany will accept approximately one million refugees in 2015, none of whom fall within the category of those who sought asylum in frontline Member States. ${ }^{147} \mathrm{Un}$ der these circumstances, it is not hard to see what real-life effect Article 78(3) TFEU on the relocation system for the benefit of Italy and Greece actually has on the course of the present refugee crisis. The effect is marginal, but just enough so that nobody can say that the centralised Union is doing absolutely nothing substantive to tackle the refugee crisis.

Despite all these legal interpretations, facts, numbers and common sense, the system of temporary protection has not been activated. In 2013, the Parliament ${ }^{148}$ did call on the Commission to consider this system as one of the options for handling current and future inflows of Syrian refugees - which all happened very early after the commencement of the Syrian civil war. Since then, however, no European institution has invoked this option for the ongoing refugee crisis. The system was not publically considered at all, except for a few authors and NGOs invoking it as the most practical and efficient framework for the EU to deal with mass influx situations, while at the same time safeguarding the fundamental rights of refugees. ${ }^{149}$

145 ibid. Interestingly, 98 out of 148,000 refugees (mostly unregistered in Greece) sought asylum in Hungary under the Dublin rules in the first 8 months of 2015. That is, before Hungary closed its borders with Serbia in mid September 2015 and before the Western Balkans route was redirected to Croatia. This is particularly relevant in the context where Janos Lazar, the minister in charge of the Hungarian Prime Minister's Office, makes public statements that refugees should be returned to Greece where they had first entered the EU. See "Hungary "will not accept" refugees from other EU states (World Bulletin, 30 October 2015) <http://www.worldbulletin.net/news/165806/hungary-will-not-accept-refugeesfrom-other-eu-state> accessed 28 December 2015.

146 See Ministry of the Interior of the Republic of Croatia, 'Information on Accepting and Accommodating Migrants in Croatia'<http://www.mup.hr/219671.aspx> accessed 5 December 2015.

147 See 'One Million Refugees may Arrive in Germany This Year' (Al Jazeera, 14 September 2015) http://www.aljazeera.com/news/2015/09/million-refugees-arrive-germanyyear-150914101006005.html accessed 30 November 2015, or 'Germany Expects up to 1.5 Million Asylum Seekers in 2015, Says Report' (The Guardian, 5 October 2015) <http: / /www. theguardian.com/world/2015/oct/05/germany-now-expects-up-to-15-mln-migrants-in2015-report> accessed on 30 November 2015. Other Member States such as Sweden, Austria, France, etc, also took in their fair share of refugees. The author will however focus on the German example as the most drastic case.

148 European Parliament resolution of 9 October 2013 on EU and Member State measures to tackle the flow of refugees as a result of the conflict in Syria (2013/2837(RSP)), para 14: '[The Parliament] calls on the Commission ... to work on contingency planning, including the possibility of applying the Temporary Protection Directive, if and when conditions demand it'

149 See, for example M Ineli-Ciger, 'The Missing Piece in the European Agenda on Migration: The Temporary Protection Directive' (EU Law Analysis, 8 July 2015) <http: / / eulawa- 
The mechanism of the Temporary Protection Directive has, actually, never been activated in the European Union. The only official request to the Commission to consider drafting a proposal for activation was made by Italy in 2011, in the context of the Libyan refugees crossing the Mediterranean in boats trying to reach the Italian shores. Although initially the Commission did consider it, ${ }^{150}$ the proposal was never submitted to the Council. The Commission believed there was no need for temporary protection in that situation due to the limited number of arrivals. ${ }^{151}$ Drawing from the Kosovo experience that motivated the drafting of the Directive, the number of people fleeing Libya was considered insufficient when compared to the 500,000 that were fleeing Kosovo. The same logic of comparison with the Kosovo situation was, however, never used in the context of the current refugee crisis where the number of displaced persons on their way to the territory of the Union is more than twice the size. ${ }^{152}$

nalysis.blogspot.hr/2015/07/the-missing-piece-in-european-agenda-on.html> accessed 28 December 2015; C Orchard and A Miller, 'Protection in Europe for Refugees from Syria' (Forced Migration Policy Briefing 10, September 2014) <http://www.rsc.ox.ac.uk/files/ publications / policy-briefing-series/pb10-protection-europe-refugees-syria-2014.pdf > accessed 28 December 2015; C Orchard and D Chatty, 'High Time for Europe to Offer Temporary Protection to Refugees from Syria?' (Oxford Human Rights Hub, October 2014) <http:// ohrh.law.ox.ac.uk/high-time-for-europe-to-offer-temporary-protection-to-refugees-fromsyria/> accessed 28 December 2015; E De Capitani, 'Mediterranean Humanitarian Crisis: If Not Now, Then When Will the EU Trigger the “Temporary Protection" Mechanism"?' (European Area of Freedom Security Justice, April 2015) <http:/ free-group.eu/2015/04/20/ mediterranean-humanitarian-crisis-if-not-now-when-the-eu-will-trigger-the-temporaryprotection-mechanism/> accessed 28 December 2015; Human Rights Watch, 'EU: Provide Protection for Syrian Refugees: Allow Access to EU Territory, Step Up Assistance in Region' (23 December 2012) <https://www.hrw.org/news/2012/12/23/eu-provide-protectionsyrian-refugees $>$ accessed 28 December 2015; Boston University International Human Rights Clinic, 'Protecting Syrian Refugees: Laws, Policies, and Global Responsibility Sharing' <http://www.bu.edu/law/central/jd/programs/clinics/international-human-rights / documents/FINALFullReport.pdf> accessed 28 December 2015.

150 The Commission, in turn, only considered introducing a temporary situation in 2011 for the refugees fleeing conflict in Libya. See Commission Press Release, 'The European Commission's Response to the Migratory Flows from North Africa, 8 April 2011, MEMO/11/226 <http://europa.eu/rapid/press-release_MEMO-11-226_en.htm?locale=fr> accessed 28 December 2015: 'The Commission would also be ready to consider proposing the use of the mechanism foreseen under the 2001 Temporary Protection Directive, if the conditions foreseen in the directive are met. Consideration could only be given to taking this step if it is clear that the persons concerned are likely to be in need of international protection, if they cannot be safely returned to their countries-of-origin, and if the numbers of persons arriving who are in need of protection are sufficiently great. Resort to this mechanism would allow for the immediate protection and reception in the territory of EU Member States for persons concerned, as well as offering a "breathing space" for the national asylum systems of the Member States most directly affected'.

${ }^{151}$ M Garlick and J van Selm, 'From Commitment to Practice: The EU Response' (Forced Migration Review) <http://www.fmreview.org/north-africa/garlick-vanselm.html\#sthash. iewe7fJK.dpuf> accessed 28 December 2015.

${ }^{152}$ Under these circumstances, it is very difficult to comprehend the refusal to activate the system for the numbers in 2015 . The only difference in treatment that one could plainly see 
Under these circumstances, one cannot but wonder why temporary protection was never put on the Union's table.

The initial reaction might be its ambiguous referral to the voluntary participation of the Member States. In other words, some Member States could simply refuse to participate. However, the arguments presented above prove exactly why the temporary protection system, even if activated only in some of the EU Member States, is more effective in tackling mass inflows than any possible Dublin exception. Moreover, nothing would prevent the Union from introducing legislative amendments to the Temporary Protection Directive so as to remove these textual ambiguities and solve the situation, just as it did with the relocations schemes through Article 78(3) TFEU or the proposed amendments to the Dublin Regulation.

The refugees that have recently arrived in the EU illegally could as well have arrived onto the Union territory legally. The inflows would most likely be less drastic, as the temporary protection system would include only the most affected nationalities of refugees, thus discouraging those who do not qualify from joining the masses entering the Union territory. By reducing this pull factor, there would also be fewer abuses of the EU asylum system. Truly displaced persons could have been transferred to Member States of destination through a temporary protection scheme in precisely the same numbers as the existing ones, only through a more coordinated (EU financed) system of transfers. ${ }^{153}$ Sticking to the Dublin rules, with the marginal impact of Dublin exceptions, led to most of the displaced persons creating the Western Balkans route, and in the end reaching their destination anyway. Money and operating capacities could have been spent on coordinated transfer activities, instead of on fortifying the border controls in EU Member States on the Western Balkans route, even between the EU Member States themselves, inside or outside the Schengen system. In other words, nothing would have changed regarding the number of actual receptions into the EU - only the status of displaced persons would not have been illegal and outside the Union law framework, but legal. The application of this system could have increased confidence that the EU could provide an adequate legal and operative

between the situation in Kosovo and the one currently ongoing is the ethnic origin and religion of the displaced persons. Note, however, Article 21 of the Charter: 'Any discrimination based on any ground such as sex, race, colour, ethnic or social origin, genetic features, language, religion or belief, political or any other opinion, membership of a national minority, property, birth, disability, age or sexual orientation shall be prohibited' (emphasis added). The Charter is, pursuant to Article 51, addressed to all Union institutions and all Member States when they are implementing Union law - such as the Temporary Protection Directive, or, to the same extent, any other aspect of the Common European Asylum System.

${ }^{153}$ See Temporary Protection Directive (n 103) Art 24. Measures undertaken pursuant to this Directive would be financed from the European Refugee Fund. 
framework for tackling the refugee crisis, even if only for those Member States who wish to participate.

\section{Consequences of misconception: EU decentralisation}

As described in the previous section, all possible justifications about why temporary protection was not activated could be repudiated as a matter of fact or as a matter of law. However, even if the reasons why temporary protection was not invoked are unclear, this does not mean that there is no underlying rationalisation. The misconception of the EU's management technique of handling the refugee crisis cannot be 'unintentional'. No one could ever claim that temporary protection was never contemplated, or that the Commission or the Council just forgot that this Directive existed within the framework of the Common European Asylum System.

There could be many explanations for the present outcome. However, the author's position is that temporary protection was never invoked due to pure politics at the level of the centralised Union and its institutions.

For the European Union in its centralised capacity, the Dublin exceptions route that was taken is much less costly, politically speaking. In other words, it is much easier for Union institutions to try things out with small-scale relocations within the Dublin system of responsibility sharing which is still suitable for the majority of EU Member States. As a consequence, the minority of frontline Member States remain at fault for the disastrous scale of refugee migrations in the EU. The route taken does not require much political will or strength, as it proves to be much easier than mobilising the entire EU (or the majority of its Member States) with a temporary protection mechanism. If the system introduced by the centralised EU does not work large-scale, the EU would be the one to blame for the system and for the Union border controls falling apart. Sticking to the responsibility of frontline Member States who must be helped, instead of seeing this as a true problem of solidarity of the Union as a whole, allows the central EU institutions to point the finger at somebody else.

Masking the shortcomings in the EU crisis management with invocations of superficial solidarity hides the fact that the Union has failed to fulfil its own responsibilities towards the Member States. It is important to note that the Union itself is obliged to confront the refugee crisis. By taking over competences in asylum and migration matters under Title V, and by harmonising the legal framework of the Common European Asylum System, the Union took over responsibility from the Member States to ensure their compliance with the Geneva Convention. In other words, it was the Union's role to activate the system that would provide a legal 
and more efficient framework for the Member States to respond to migratory pressures. However, instead of activating temporary protection and an emergency system of asylum claims responsibility envisaged for situations of mass influx, the EU still forces the Dublin system as a default, introducing into that system a set of diverse exceptions whose overall effect is nothing but marginal in the given context. The Union failed to provide a more efficient response to the migratory pressures available in its own legal framework in time, and is now covering its tracks.

As a result of Union inaction, it was the Member States who took the wheel and placed themselves in charge of handling the refugee crisis, each on its own behalf. The marginal results of the Union Agenda measures effectively mean that the EU stepped aside as the main actor of refugee crisis management, creating the perfect ground for Member States to invoke their own political particularities and national interests. The outcome was polarisation of the Member States - the first step in creating a two-fold Europe, each day moving farther away from the evercloser Union. ${ }^{154}$

The first fraction of the Member States, led by Germany, took over the responsibility of international refugee protection from the European Union. In a constitutional context, one might see this as a reverse subsidiarity situation, where certain Member States took over the competence in asylum law and policy from the Union which proved to be incapable of handling the situation itself. ${ }^{155}$ These Member States followed their obligations arising from the Geneva Convention, thus also saving the European Union from being accused of violating refugees' fundamental rights. ${ }^{156}$ They stepped up when the central EU response fell short. Whatever their motives, whether compensating for the past, adhering to fundamental rights or purely humanitarian grounds, it was only one part of the Member States who took the burden for Europe. However, the only way for those Member States to do so was to disregard the existing Union

\footnotetext{
154 To that extent, it is interesting to note that Jean-Claude Juncker himself started publicly speaking about a two-speed Europe: 'One day we should rethink the European architecture with a group of countries that will do things, all things, together, and others that will position themselves in an orbit away from the core'. See E Zalan, 'Juncker Foresees Two-Speed Europe (EUobserver, 10 November 2015) <https://euobserver.com/institutional/131172> accessed 28 December 2015. This seemingly marginal statement of the EU's highest executive official may, however, uncover the true vision for the future of Union.

155 This argument is specifically interesting in the German context and the Solange saga: because the EU response fell short of the level of protection of fundamental rights required by the German Basic Law, Germany no longer recognises the supremacy of EU law and is allowed, in its national constitutional capacity, to put Union rules on the CEAS out of effect. 156 Taking over the competences in asylum matters, but not activating an effective emergency system capable of handling the existing refugee crisis, the Union could de facto be responsible for violations of the Geneva Convention. Luckily, the EU is currently saved by efforts of these individual Member States who took over the role of providing international protection to refugees.
} 
asylum rules, effectively putting out of force and out of practice the EU Dublin Regulation. In a way, the good guys of the story created anarchy in Union asylum law. ${ }^{157}$

As previously stated, the Western Balkans route was developed as a by-product of Germany accepting a 'million' refugees in order to adhere to the Geneva Convention. It is thus quite ironic to observe that it was precisely this Western Balkans route that resulted in a chain reaction that turned Member States against each other, practically disregarding the entire Union legal framework on asylum. The result was systematic failures to register refugees and illegal migrants; the crushing of the Union's external and internal borders; massive inflows of refugees in Hungary, Croatia, Slovenia, Austria, etc; unregulated secondary movements; inhumane treatment of refugees along the route; human trafficking and smuggling; and the collapse of the much needed control of borders for security reasons. ${ }^{158}$

Quite conveniently, this situation also created a perfect excuse for the formation of a second fraction of EU Member States - those who oppose accepting refugees and who challenge the quotas for relocations (for quite marginal numbers as compared to the overall EU acceptance rates); those soliciting the closing of European borders; those who build fences and surround the Union's external and internal borders with barbed wire; those who invoke Schengen exceptions to the point where a 'Union without internal borders' makes no practical sense whatsoever. ${ }^{159}$ Some of these actions may well be radical, and some could be justified under current circumstances. Altogether, they serve to further deepen the existing divergences between the Member States' individual national interests.

It is precisely at this point that the convenience of using a temporary protection schemes must again be emphasised.

\footnotetext{
${ }^{157}$ Admittedly, some might claim that Germany is acting within the scope of the Dublin Regulation by using the sovereignty clause exception (Article 17 of the Dublin Regulation), which allows taking over the responsibility of examining asylum applications from another Member State. In the context of Germany taking over more than a million refugees, twothirds of the entire number of refugees currently in the EU, invoking this exception of the Dublin Regulation could only be seen as stretching the system to absurd lengths.

${ }^{158}$ An attempt to handle the chaos of the Western Balkans route was also subject to a special meeting of leaders of affected EU and non-EU states on 25 October 2015. See Leaders' Meeting on Refugee Flows Along the Western Balkans Route, 'Leaders' Statement' < http:// ec.europa.eu/news/2015/docs/leader_statement_final.pdf> accessed 28 December 2015. Furthermore, the security reasons seem specifically prudent in the aftermath of the 13 November 2015 Paris terrorist attacks.

159 For more information on invoking exceptions to the Schengen system, see S Peers, 'Can Schengen Be Suspended Because of Greece? Should It Be?' (EU Law Analysis, 2 December 2015) <http:/ / eulawanalysis.blogspot.hr/2015/12/can-schengen-be-suspended-becauseof.html?utm_source=feedburner\&utm_medium=email\&utm_campaign=Feed:+EuLawAnaly sis $+($ EU+Law+Analysis $)>$ accessed 28 December 2015.
} 
Temporary protection is not just a system that protects individual refugees under its scope. It also protects the EU Member States from the chaos that is an inevitable result of an unmanaged crisis. By automatically granting protection to all those who fall within the definition of war-displaced refugees, a temporary protection scheme also reduces pressures at the external and internal borders. It comes with financial support and an administrative framework for cooperation among Member States through a pre-designed system of coordinated transfers of refugees from the frontline countries to their final destination, minimising secondary movements. It also ensures that all the Member States take on part of the formal initial responsibility for processing asylum claims, thus relieving the Member States on the periphery from the pernicious political pressure of being responsible and constantly fearing mass returns of refugees.

If a temporary protection scheme was activated in time, there might not have been the Western Balkans route, or at least not on the present scale. Operative resources could have been redirected to the external borders to more effectively safeguard entries into Union territory for the safety of all the EU Member States and all EU citizens. Financial resources could have been used, instead of for blankets and paying for barbed wire on the Union's internal borders, for subsidising or financing the Member States' efforts for transferring Syrian, Afghan and Eritrean refugees from Greece and Italy to the Member States of their destination. Internal EU borders would be safer, and there would be no need to close them in such a systematic manner. Schengen would perhaps function better. In other words, there would be no underlying reason for preventing secondary movements by putting up barbed fences between EU Member States and EU neighbours. In the context of the EU wrapped in barbed wire, even the 'Fortress Europe' attribution may start to seem an understatement. By using the temporary protection scheme in a timely manner, we could perhaps have avoided the existing chaos.

If this system were indeed applied in practice, nobody doubts that the Union would still face a number of problems it is facing anyway. Like all other theoretical ideals, temporary protection would surely result in a number of practical difficulties. If the EU had invoked it, there most certainly would have been a small mutiny of some Member States, accusing the Union of centralisation, competence theft and violations of their public policy or public security exemptions. Furthermore, the system of coordinated administrative and operative action for transfers would certainly not function as it should. Other practical difficulties would paralyse the system from time to time, as that is inherent in the very definition of a crisis situation. 
Nonetheless, it may be argued that one simple added value of a temporary protection mechanism overcomes all the difficulties of EU refugee crisis management - EU Member States would have a Union-introduced legal system to work with. All efforts undertaken by the Member States would be within the existing Union legal framework. In other words, the Member States would not be forced by the Union's own hand to effectively put the Dublin rules, and consequently the Union legal framework on asylum, out of effect.

\section{Conclusion}

By activating the European Agenda on Migration, the EU has implemented a wide set of legal, financial and operative measures to face the challenges of the ongoing refugee crisis. Some of these measures aim to respond to what was classified as the most pressing duty of saving lives in the Mediterranean. The EU has also stepped up in the international arena to uphold its international obligations and values by assisting the third countries most affected. Alongside the humanitarian approach, the EU has also strongly committed itself to doing everything in its power to secure the Union's external borders. The final set of emergency measures was then introduced to repair the existing legal framework on asylum, proven as dysfunctional when faced with the pressure of mass inflows of refugees. Overall, the European Union has indeed done more than any other significant actor in the Western world to respond to the humanitarian crisis. For this reason, the overall critique of the EU crisis management technique must to a certain extent be attenuated. Nonetheless, considering the background of the EU's commitment to introduce a coherent and effective asylum policy and legal framework, the author's position is that the EU could have done it differently, and could have done better.

The Agenda on Migration came about in the already existing context of a deficient Common European Asylum System. Yet the Dublin Regulation for determining the Member States responsible for asylum seekers, being the core problem of the CEAS, was nonetheless placed as a starting point for all operative plans of EU crisis management within the Union territory. In other words, all Union measures introduced to address internally the crisis presuppose that the Dublin system is a default rule - starting from the presumption that initial legal responsibility lies with the frontline Member States who are then aided by measures for transferring that responsibility to other Member States. Diverse exceptions were introduced to the otherwise applicable Dublin rules, creating effects that are nothing but marginal in the given context. The most important exception to that extent - that is, the relocation of 200,000 people from Italy and Greece - legally covers only around $20 \%$ of the refugees accepted 
overall into the Union territory in 2015. The remaining numbers of refugees simply do not fall within the existing EU framework on asylum, but have been accepted through individual efforts of EU Member States.

The author submits that the reason for this inconsistency lies precisely in the EU's misconception of basing the entire EU crisis management measures on the Dublin presumption. The Dublin Regulation was simply not envisaged to function at a time of crisis. Introducing the exceptions to that already inefficient system was predestined to fail. Amending an inherently dysfunctional framework may well be seen as saving a system that cannot be saved in the given context.

Ironically, the emergency legal setting was not something the Union was unequipped for during the crucial moments of creating the operative plan for the Agenda. The existing framework of the Common European Asylum System creates two quite different concepts for determining the Member State responsible for providing international protection to refugees. In addition to the Dublin Regulation, the CEAS also includes a responsibility-sharing mechanism prescribed in the Temporary Protection Directive.

In the words of the Commission, this Directive should be activated in cases of a mass influx of displaced persons in order to (1) deal with the influx in a uniform, balanced and effective way, based on solidarity; (2) ensure that the default asylum system does not collapse, and (3) preserve intact the operation of the Geneva Convention. ${ }^{160}$

The mere fact that the Temporary Protection Directive exists corroborates the conclusion that the already dysfunctional Dublin Regulation is not the proper legal basis for the functioning of CEAS in crisis situations, but only in situations within the 'normal' sphere. Measures currently introduced cannot be effective in practice when their legal setting is based on underlying assumptions that were not envisaged for emergency situations. In other words, the EU crisis management technique is simply set within the wrong legal framework.

At a time of crisis, the starting point should have been the initial shared responsibility of all Member States based on solidarity, precisely as envisaged in the Temporary Protection Directive. The Agenda itself recognises that, in emergency situations, no Member State can effectively address migration alone. A new, more European approach based on solidarity would be needed. ${ }^{161}$ Unlike the Dublin first country of entry

\footnotetext{
${ }^{160}$ Commission Press Release, Temporary Protection in the Event of a Mass Influx of Displaced Persons', ip/00/518, 24 May 2000 (press release following the Commission's Proposal for the Temporary Protection Directive) <http://europa.eu/rapid/press-release_IP00-518_en.htm?locale=en> accessed 28 December 2015.

${ }^{161}$ Agenda on Migration (n 6) 2.
} 
concept, a temporary protection mechanism presupposes that responsibilities for refugees are mutual and binding on all the Member States.

The current EU refugee crisis management nonetheless failed to invoke the temporary protection scheme envisaged to deal with the influx in a balanced and effective way based on solidarity. If the temporary protection mechanism had been activated, the Union action would have been considered fully in line with the original purpose and function of the 1951 Geneva Convention which was created in the aftermath of World War II, intending to provide international protection to all masses fleeing events occurring before 1951. ${ }^{162}$

On the other hand, the Union's current Dublin-based efforts resulted in a collapse of the EU asylum system and brought into question the conformity of the core set of EU actions with the Geneva Convention. The sole reason why the EU is currently not in breach of those international obligations is due to the unilateral actions of individual Member States that are outside the EU legal framework. Precisely because the EU forces Dublin as a default, it failed to provide Member States with efficient and working solutions to the unstoppable pressures of the incoming refugees. The EU has not done enough to create a functional legal system that is truly capable of tackling the refugee crisis of the present magnitude. In other words, by failing to recognise the core problems of its existing default approach to the Dublin Regulation, the EU allowed its own asylum system to collapse - simply by insisting on the application of the wrong European rules.

By not providing Member States with a functioning legal framework to work with, the EU is forcing its Member States to act individually, allowing their particular political interests to prevail. One part of the Member States pursued those interests to fulfil the true Geneva purpose, thus taking on almost the entire burden for Europe. Most other Member States stepped aside, while some of them systematically kept closing their borders and building barbed wire fences between the EU Member States and EU neighbours in the name of salvaging the Dublin system. If the EU had indeed equipped the Member States with a decent framework for administrative cooperation and organised transfers accompanied by EU funds, perhaps there would not have been a West Balkans route that is causing most of the problems in preventing secondary movements.

To that extent, it must be emphasised that temporary protection is envisaged to work for the benefit of the Member States, in addition to

\footnotetext{
${ }^{162}$ Before the 1967 Protocol expanded its territorial and temporal scope, so that the Convention applies to all those who fall within the definition of a refugee. See Office of UNHCR, 'Introductory Note to the Geneva Convention' <http://www.unhcr.org/3b66c2aa10.html> accessed 28 December 2015.
} 
upholding the fundamental rights of individual refugees. It reduces pressures at the borders by providing for an administrative framework for the cooperative transfers of refugees from the frontline Member States to their destinations. This is a system that could have saved Member States from introducing exceptions to the Schengen system, and thus effectively putting out of practice the idea of a Europe without internal borders. Moreover, the temporary protection scheme would ensure that all Member States take on responsibility from the very beginning, relieving the frontline Member States from the pernicious political pressure of being the ones to blame for the chaos of secondary movements, while constantly fearing mass returns.

However, the policy choice of avoiding the temporary protection scheme could not have been unintentional on the side of the central EU institutions. Focusing on Dublin must be seen as a cognitive political choice, giving the Union institutions someone else to blame for the collapse - namely, the frontline Member States who bear the initial responsibility for the asylum seekers. In the real-life context, the crisis management route chosen has proven to be even more inefficient. Furthermore, if the large-scale system of temporary protection was indeed proposed, and if the Member States disagreed, this would effectively bring to light that perhaps there was no European Union that was ever closer, and that the idea of Union integration based on solidarity exists only within the scope of the economic internal market. Mobilising the entire European Union contrary to the preferences of individual Member States (on such a politically sensitive issue such as asylum law) could suggest that there is no Union as a constitutional quasi-federal legal order based on common underlying values of fundamental rights protection with no individual exceptions.

The Agenda itself admits that

one of the weaknesses exposed in the current policy has been the lack of mutual trust between Member States, notably as a result of the continued fragmentation of the asylum system... But the EU has common rules which should already provide the basis for mutual confidence, and a further development of these rules will allow for a fresh start. ${ }^{163}$

The measures chosen to activate the Agenda, however, were not those common rules that could have restored the invoked mutual confidence. Quite the contrary, the path taken resulted in even further fragmentation of the asylum system where only one Member State takes almost two-thirds of the entire burden for Europe. The Union's own choice

${ }_{163}$ Agenda on Migration (n 6) 6. 
has resulted in what the Agenda sought to attenuate - Member States growing even further apart. By refusing to confront these issues, the EU institutions avoid admitting that the ideal Union integration is currently facing its ultimate identity crisis and that the political particularities of individual Member States still condition the core selective unity for the peoples of Europe. 